\title{
HEALTH CONDITIONS OF IMMIGRANT JEWS ON THE LOWER EAST SIDE OF NEW YORK: 1880-1914
}

\author{
by
}

\section{DEBORAH DWORK*}

'Golden thread, you are part of the weaving now.'

Health Conditions of immigrant Jews on New York City's Lower East Side are discussed in light of the circumstances of their lives before and during migration. In addition to morbidity and mortality data, the interrelated effects of poor sanitation, occupational hazards, and poverty are shown on the physical, emotional, and family health of these turn-of-the-century immigrants. Also examined is the surprising finding that despite conditions which normally engender disease, the physical health of Jews was remarkably good in comparison to that of both non-Jewish immigrants and native-born Yankees.

This was true not only of immigrant Jews in America; surprisingly, Jews in Europe were, on the whole, also healthier than their Christian countrymen. Although the great majority of Jews in Europe as well as America lived in the most overcrowded and unsanitary quarters of the cities, and under difficult social conditions, available statistics (some fragmentary, others extensive) and contemporary reports of practising physicians show that they had lower morbidity and mortality rates than their nonJewish neighbours.

Contemporary medical and social investigators believed three major factors to be responsible for the Jews' generally low disease rates: rare alcoholism, religious law, and social customs, particularly family structure, traditions and behaviour patterns. Infant and child mortality rates were lower among Jews than their neighbours, and this was thought to be the result of Jewish concern for child welfare. These possible explanations will be discussed more fully later. Interestingly, these factors which fostered health among Jews were most severely strained by the Americanization process.

II

The mass immigration of Eastern European Jews to the United States occurred between 1880 and $1914 .{ }^{* *}$ From 1881 to $1900,675,000$ Jews entered the United

\footnotetext{
* Deborah Dwork, B.A., M.P.H., Wellcome Institute for the History of Medicine, 183 Euston Road, London NWI 2BP.

** Between 1820 and 1870 , Jews comprised 0.4 per cent of the total number of immigrants to the United
} 


\section{Deborah Dwork}

States; from 1901 to 1914 the number doubled to approximately $1,346,000 .^{3}$ The dates 1880-1914 are related to specific historical events: the assassination of Tsar Alexander II with its subsequent pogroms, and the beginning of World War I. In the thirty-three years between these two events, over two million Jews, or one-third of the Jewish population of Eastern Europe, came to the United States. Prior to 1881, Jews emigrated in search of a less oppressive society. Then, as a result of three events, the character of Jewish emigration changed. First, the assassination of Tsar Alexander II unleashed a fury of pogroms, which continued intermittently at least until World War I. A mass exodus of Russian Jews occurred following the 1881 pogroms, the 1903 Kishinev massacre, and pogroms following the unsuccessful revolution of 1905. Second, the increased legal restrictions on Jews, such as the so-called May Laws of the 1880s, forced Jews to abandon their previous employments and way of life and to migrate to urban centres. Prohibited from owning or renting land outside towns and cities, industrialization encroaching rapidly on their occupations as artisans and craftsmen, Jews turned to the industrial labour force. The population of Jews in Lodz soared from eleven in 1793 to 98,677 in 1897 and 166,628 in 1910. Similarly, Warsaw had 3,532 Jewish inhabitants in 1781 and 219,141 in 1891.4 These migrations within Russia and Poland were often only temporary solutions to the problem of survival, especially for young skilled Jews who saw no future in the cities. Finally, the decline of Central European emigration to America encouraged the German transatlantic passage companies to seek out Eastern Europeans as new passengers. ${ }^{5}$

There were also more private reasons for leaving: to escape military service; lack of a dowry; hunger. They left because the others were dead, or had left already. They left because "the struggle for living was too great and hard... . The persecution of the Jews became unbearable." "People who got it good in the old country don't hunger for the new."

The Jewish immigration was a movement of families. Between 1886 and 1896, an average of 41.6 per cent of Jewish immigrants entering the port of New York were women, and 33.8 per cent were children under sixteen years of age. This continued after the turn of the century. From 1899 to 1910 , women accounted for 43.4 per cent

States. Between 1871 and 1880 , this rose to 2.5-per cent, and from 1881 to 1890 , it again rose to 3.8 per cent. From 1891 to 1900 the Jewish ranks swelled to 10.8 per cent. This translates into 850,000 to 900,000 Jews entering the United States during the nineteenth century. Of these 700,000-750,000 were Eastern European and approximately 150,000 were Germans.' It is important to note that exact statistics are not available because the term "Hebrew" was not adopted in the United States until 1899; pior to that immigrants were classified by country of origin. Numerical estimates were made using the combined records of philanthropic organizations and the government. ${ }^{2}$

\footnotetext{
'Jacob Lestschinsky, 'Jewish migrations, 1840-1956', in Louis Finkelstein (editor), The Jews, vol. II, New York, Harper, 1960, p. 1561.

2 Ibid., p. 1553.

3 Ibid., p. 1554.

\Moses Rischin, The promised city, Cambridge, Mass., Harvard University Press, 1962, p. 24.

sIbid., pp. 19-20.

' Michael Charnofsky, Jewish life in the Ukraine, New York, Exposition Press, 1965, p. 223.

7 Anzia Yezierska, Hungry hearts, Boston, Houghton, Mifflin, 1920, p. 56.
} 
of the Jewish immigrant population, and children under fourteen years of age for 24.9 per cent. Nearly 70 per cent of Jewish immigrants were between the ages of fourteen and forty-four. ${ }^{8}$

For most, it was a permanent move. A smaller percentage of Jews returned to the Old World than of any other immigrant group. Between 1908 and 1924, 94.8 per cent of the Jewish immigrants, as contrasted with two-thirds of the total immigrant population, remained in the United States.'

The occupational training of Jewish immigrants changed considerably before and after 1900. Prior to 1900, there were fewer industrial workers and more artisans and people engaged in middle-man occupations. The years between 1880 and 1900 , however, saw great industrial and urban development both in Eastern Europe and the United States. Thus, later immigrants had the opportunity to learn industrial skills in Europe. Immigrants wrote to their family and friends still in Europe, extolling the virtues and necessity of industrial skills. For example, due to the geometric growth of the U.S. garment industry, young people began to take sewing lessons in preparation for emigration. "By 1900 even the daughters of respectable householders had turned their energies and talents to it."10 The hero of Abraham Cahan's novel, The rise of David Levinsky, recounts his arrival in New York:

"You're a tailor, aren't you?" [the contractor] questioned him.

My steerage companion nodded. "I'm a ladies' tailor, but I have worked on men's clothing, too," he said.

"A ladies' tailor?" the well-dressed stranger echoed, with ill-concealed delight. "Very well; come along I have work for you."

..."And what was your occupation? You have no trade have you?"

"I read Talmud," I said confusedly.

"I see, but that's no business in America."..."

The immigration statistics verify this emphasis on skilled labour. Although Jews constituted only 10.3 per cent of the total immigrant population between 1900 and 1925 , they accounted for one-quarter of the skilled industrial workers entering the United States - nearly one-half of the clothing workers, jewellers, and watchmakers; one-third of the printers; 41.4 per cent of the leather workers; and one-fifth of the shopkeepers and merchants. ${ }^{12}$ From 1899 to 1914, "Jews ranked first in 26 out of 47 trades tabulated by the Immigration Commission, comprising an absolute majority in eight."13

Immigrants often encountered great difficulties arranging passage to America. Often the male members of the family would leave first, sometimes one at a time, and live depriving themselves of all but bare necessities until they had enough money to "bring over" their wives, mothers, sisters, and children. In Anzia Yezierska's short story, Brothers, the hero Moisheh tries to save money for ship tickets for his mother and two brothers:

- Samuel Joseph, Jewish immigration to the United States, Ph.D. thesis, Columbia University, New York, 1914, pp. 176-177.

Irving Howe, World of our fathers, New York, Harcourt, Brace, Jovanovich, 1976, p. 58.

${ }^{10}$ Rischin, op. cit., note 4 above, p. 27.

1 A braham Cahan, The rise of David Levinsky, New York, Harper, 1917, pp. 90-91.

12 Lestschinsky, op. cit., note 1 above, p. 1569.

${ }^{13}$ Rischin, op. cit., note 4 above, p. 59. 


\section{Deborah Dwork}

... Moisheh the Schnorrer they call him. He washes himself his own shirts and sews together the holes from his socks to save a penny. Think only! He cooks himself his own meat once a week for Sabbath and the rest of the time it's cabbage and potatoes or bread and herring. And the herring what he buys are the squashed and smashed ones from the bottom of the barrel. And the bread he gets is so old and hard he's got to break it with a hammer. ${ }^{14}$

Even if a ticket were sent, money was needed for travel from the village or town to a port of embarkation. People simply sold all their possessions and left for America by cart, train, or on foot, with packs on their backs held in feather bedding - if that hadn't already been sold as well. If the immigrant was male and of conscription age, he had to be smuggled out of the country, and often left with no passport or identifying papers. ${ }^{15}$ Steerage from Hamburg, Bremen, or Antwerp cost \$34; from Liverpool $\$ 25$. Bribing various officials was another major expense. ${ }^{16}$

At the port the immigrants were examined by a physician. This was not done for their health, but rather with an eye to the ship company's profit: upon arrival at Castle Garden, and after 1892 Ellis Island, immigrants with incurable or contagious diseases or conditions had to return to Europe at the ship company's expense. The medical examination is the subject of the short story Off for the Golden Land by the great Yiddish author Sholem Aleichem:

The time comes to go on board the ship. People tell them that they should take a walk to the doctor. So they go to the doctor. The doctor examines them and finds they are all hale and hearty and can go to America, but she, that is Goldele, cannot go, because she has trachomas on her eyes. At first her family did not understand. Only later did they realize it. That meant that they could all go to America but she, Goldele, would have to remain here in Antwerp. So there began a wailing, a weeping, a moaning. Three times her mamma fainted. Her papa wanted to stay here, but he couldn't. All the ship tickets would be lost. So they had to go off to America and leave her, Goldele, here until the trachomas would go away from her eyes....17

The vast majority of immigrants travelled steerage class (Fig. 2). They were crammed into the bowels of the ship; some companies even locked them in to prevent them from going on the upper decks and mingling with the second-class passengers. For many the food was inedible since it was not kosher. The non-observant found it equally inedible because it was so disgusting and decayed. Many people subsisted on a diet of black bread, herring, and tea. Some were fortunate enough to have cheese and butter. Sanitation was terrible, with a few salt water basins used as dishpans, laundry tubs, and for personal hygiene. The condition of the toilets was worse - open troughs that were rarely flushed and even more rarely cleaned. Throughout their memoirs and oral histories, people recounted tales of terrible seasickness, explaining that the filth and foul smell of their surroundings alone caused nausea.

The voyage lasted anywhere from ten days to three weeks, usually it was a twoweek trip. They arrived, dazed, confused, weak from hunger and seasickness, at "The Island of Tears", Ellis Island. From all reports - those of the immigrants, officials, and the Hebrew Immigrant Aid Society - Ellis Island was a bewildering experience, full of the pain of displacement. During the late nineteenth century, a few thousand immigrants had arrived at Castle Garden each week; throughout the early years of the twentieth century, tens of thousands arrived at Ellis Island each week.

14 Anzia Yezierska, Children of Loneliness, New York, Funk \& Wagnalls, 1923, p. 127.

$1 s$ Benjamin Lee Gordon, The memoirs of a physician, New York, Bookman Associates, 1962, p. 130.

16 Howe, op.cit., note 9 above, p. 39.

"Sholem Aleichem, 'Off for the Golden Land', Jewish Immigration Bull., February 1917, p. 10. 


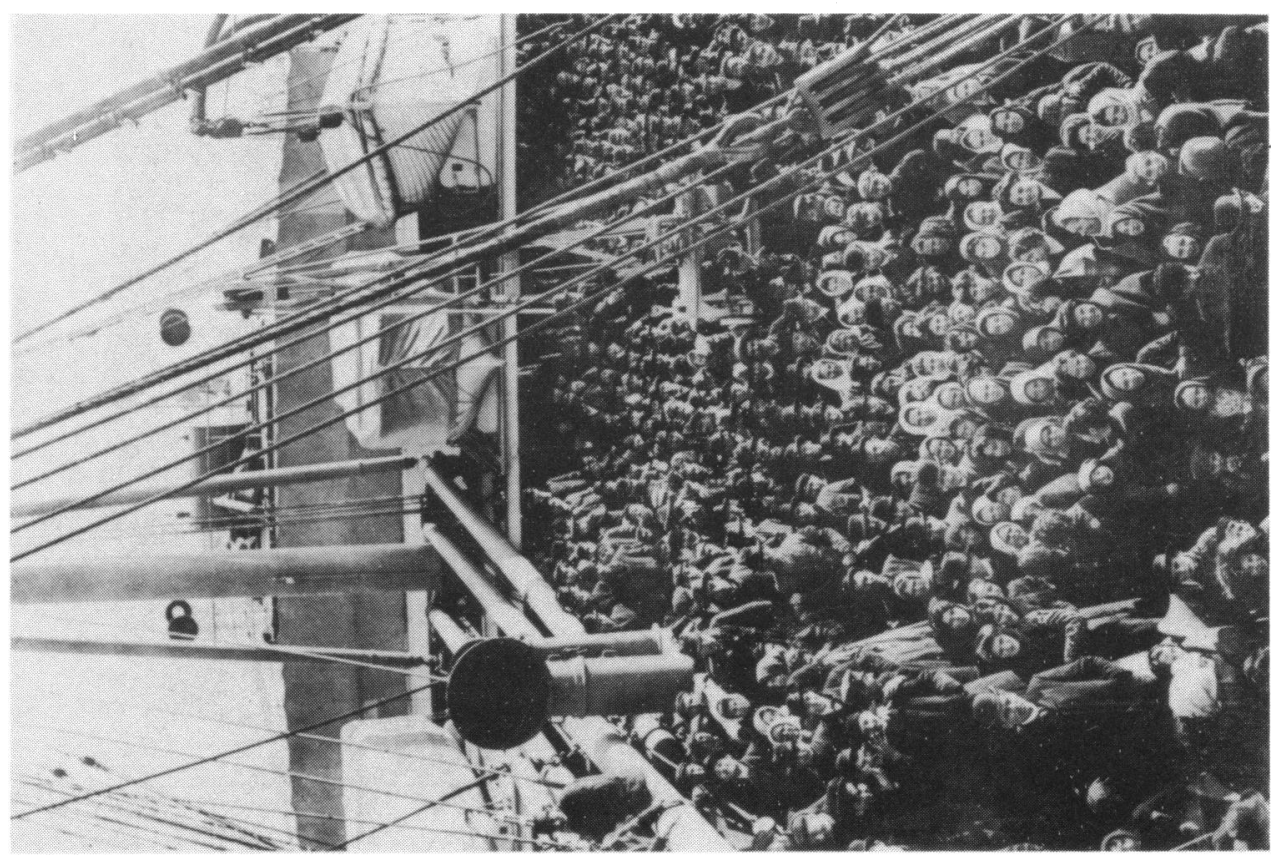



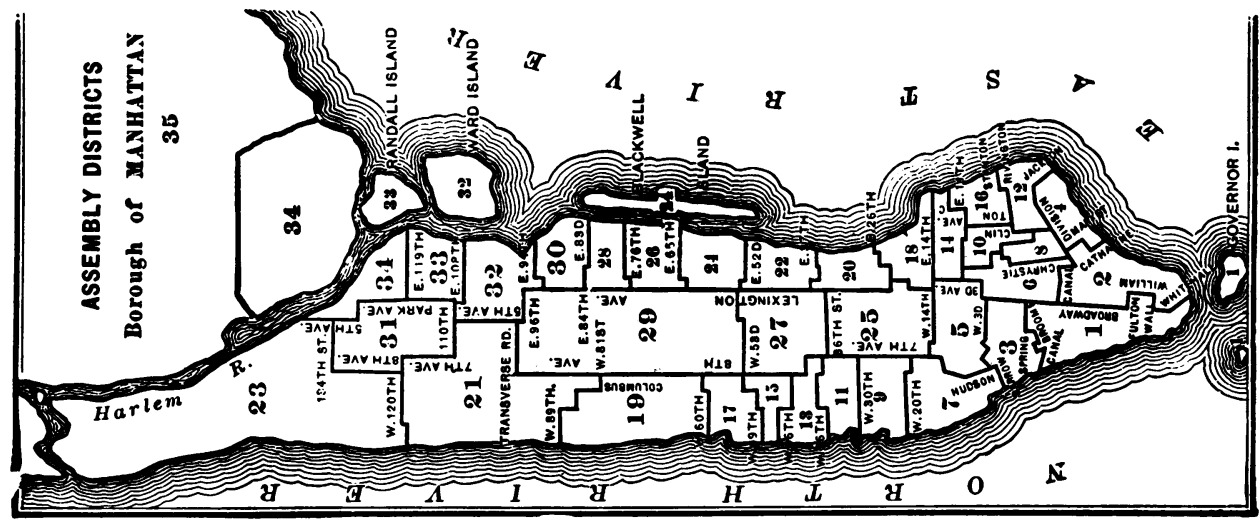





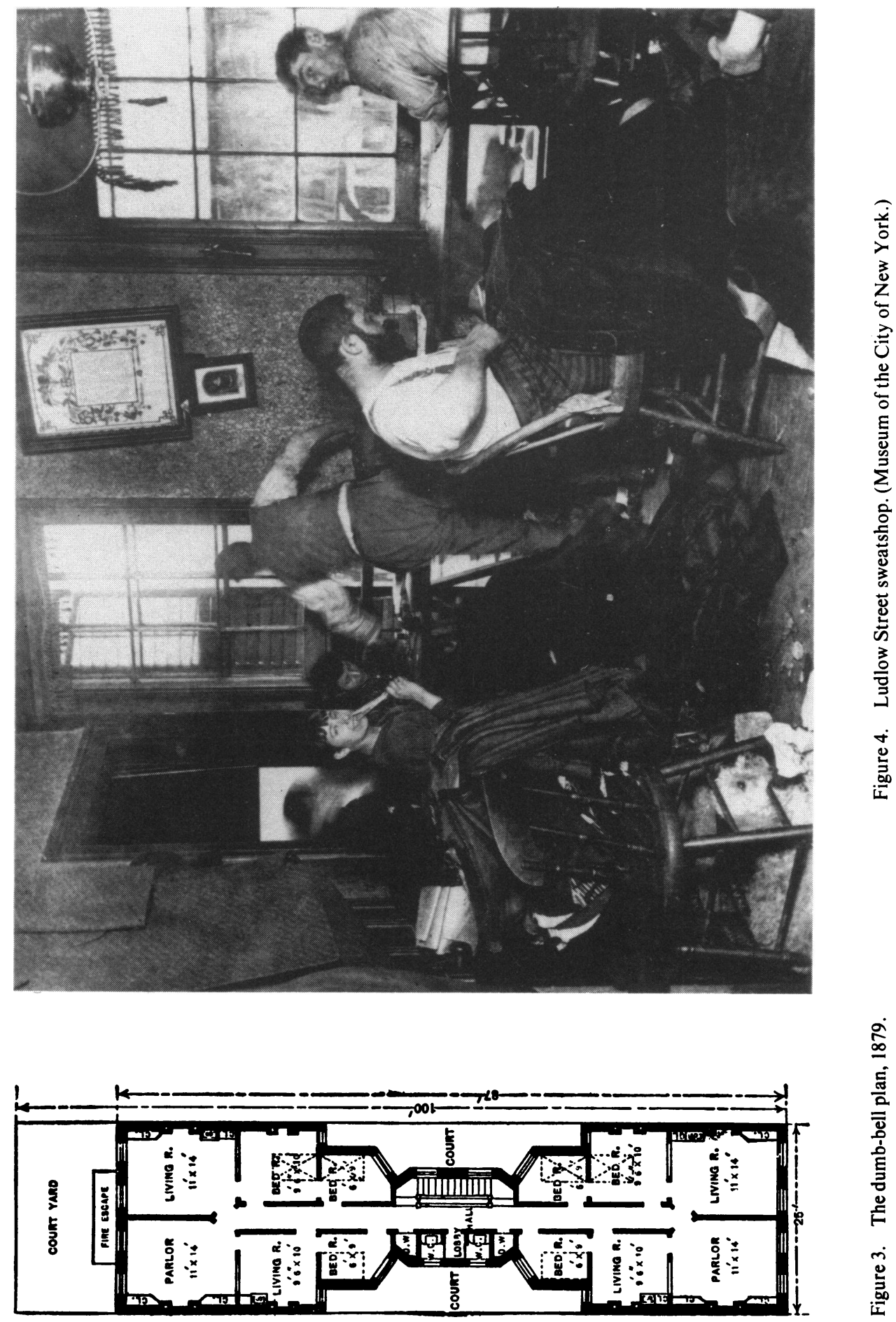




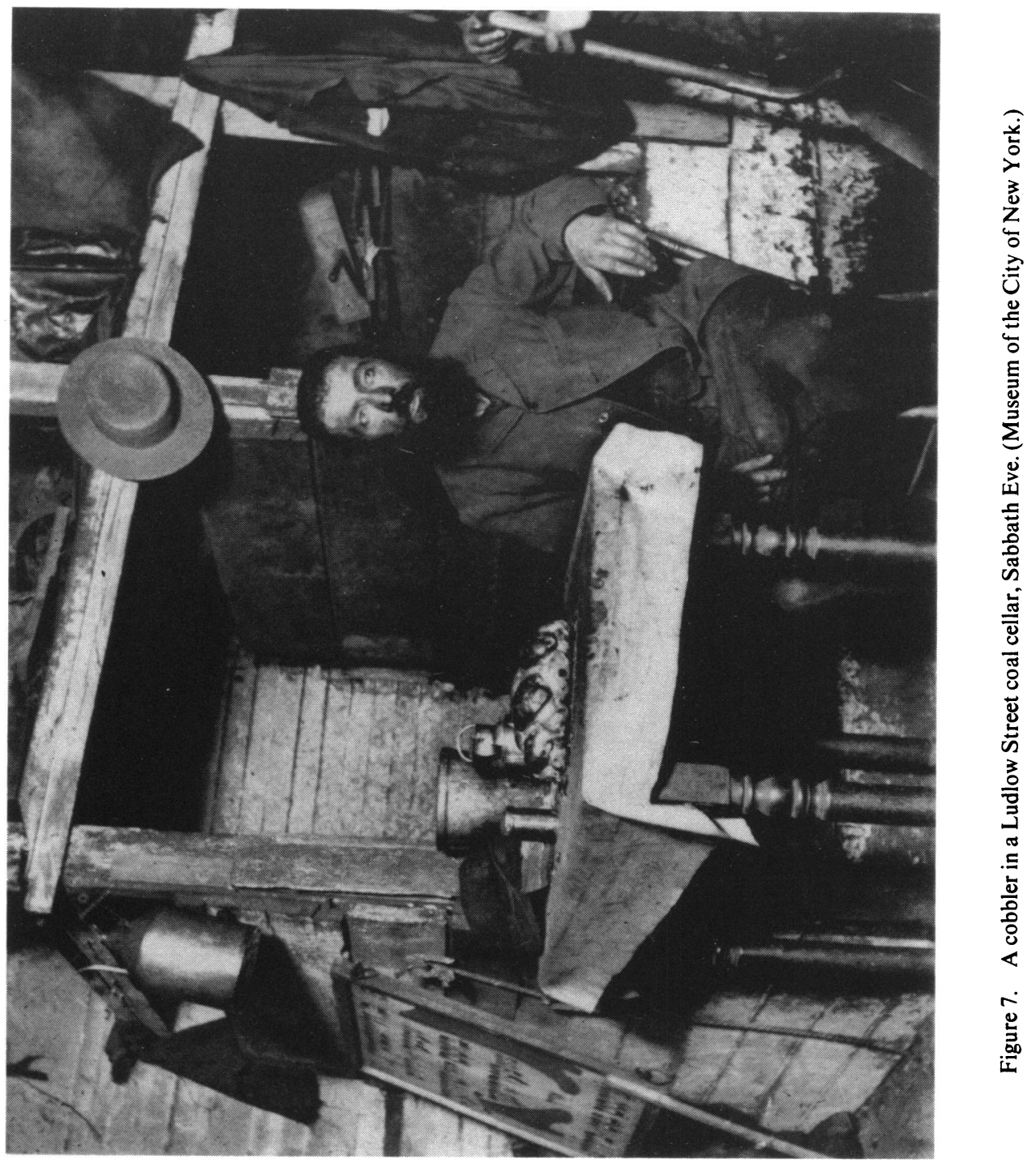




\section{III}

Each immigrant was given a medical and cursory mental examination. People with suspected problems were marked with symbols drawn in chalk on their outer garments. One immigrant recalled that day with horror:

It was so crowded and noisy. I was a small child then and held fast to my mother's hand. A man in uniform leaned down and drew a letter on my coat. I was frightened. My mother made as if it was hot and opened her cloak wide, doubling it back over her shoulders. Then, after we passed that man, she did the same to me. There were so many people, no one noticed. That's how I got into America. ${ }^{18}$

Trachoma was the cause of more than half the medical detentions, and according to a contemporary article in Scribner's magazine, "most of those detained by the physicians for trachoma are Jews." 19

Some immigrants were met by relatives, others, sometimes unexpectedly, by landsmen, or fellow-villagers. One immigrant writes that his rabbi in Russia had written to the landsmanshaften (a fraternal organization or lodge composed of fellowtownspeople) in New York on his behalf. Thus, to his surprise, he was met at the pier by an old neighbour. ${ }^{20}$ Still others were met by contractors on the watch for "greenhorns" (newcomers) experienced at their trade but not in American ways. And finally there were those, like David Levinsky, Abraham Cahan's fictional protagonist, who were simply pointed in the direction of the Lower East Side, and walked until they were greeted with recognizable signs and understandable speech.

Between 70 per cent ${ }^{21}$ and 90 per cent ${ }^{22}$ of the Jewish immigrants remained in New York, for a number of reasons. Social ties were very important. Family, friends, or neighbours might have already established themselves there. The desire to settle in a Jewish community was also of great importance. Despite a decrease in strict religious observance, certain essentials were necessary: kosher meat, a rabbi, a minyan (the mandatory minimum of ten men necessary to hold religious services). Many immigrants recalled the great uprooting and intense loneliness mitigated by homely companionship and customs. And, finally, New York was attractive because industrial work was more readily available there than in other parts of the country.

The Jewish immigrant population concentrated in the seventh, tenth, eleventh, and thirteenth wards of lower Manhattan. By 1900, Jews comprised an average of 79 per cent of the population of these wards, or an estimated 252,821 individuals. Thus, these can be considered "Jewish" wards.

The living conditions in these wards must not be romanticized. There is a common notion that poor today is not like poor then; old-time poverty was clean, honest, and upright. This is utter nonsense. Poverty, as it existed on the Lower East Side of New York, was noisy, foul smelling, diseased, hungry:

The squalid humans that swarmed about ... the raucous orchestra of voices, the metallic bedlam of elevated trains, the pounding of horses ... the teeming ghetto ... haggling pushcart peddlars ... the dirt and din of screaming hucksters.... The slattern yentehs lounging on the stoops, their dirty babies at

\footnotetext{
18 Oral history, Mrs. B., now living in New Haven, Conn.

19 Arthur Henry, 'Among the immigrants', Schribner's Mag., 1901, 29: 302.

${ }^{20}$ Charnofsky, op. cit., note 6 above, p. 224.

${ }^{21}$ Richard Wheatley, 'The Jews in New York', Century Mag., 1892, 43: 323.

${ }^{22}$ George Price, 'Russian Jews in America', Amer. Jew. Hist. Soc., 1958, 48: 42.
} 


\section{Deborah Dwork}

their breasts. . . . Wedged in, jumbled shops and dwellings, pawn shops and herring-stalls, strained together. ... Broken stoves, beds, three-legged chairs sprawled upon the sidewalk. ${ }^{23}$

The congestion was overwhelming. The New York Times reported on 18 January 1895 that sections of the Lower East Side were more densely populated than the most crowded areas of Bombay or Prague, and immigration had not yet reached its peak. The tenth ward was more densely populated than any European city, with 626.25 persons per acre as compared with 485.4 in Prague and 125.2 in Paris. ${ }^{24}$ Tables I-IV illustrate the rise in population throughout Jewish wards.

TABLE I. TOTAL POPULATION OF JEWISH WARDS IN 1890, 1900 AND 1910 AND $\%$ JEWISH IN 1900

$\begin{array}{cccccc}\text { Ward } & \text { Approx. Assembly District } & 1890^{\mathrm{a}} & 1900^{\mathrm{b}} & 1910^{\mathrm{c}} & \% \text { Jewish in } 1900^{\mathrm{d}} \\ 7 & 4 & 57,366 & & 99,721 & 60 \% \\ 10 & 8 & 57,596 & 71,879 & 109,107 & \text { nearly } 100 \% \\ 11 & 16 & 75,426 & & 61,415 & 80 \%+ \\ 13 & 12 & 45,884 & 64,117 & 78,010 & 75 \%+\end{array}$

TABLE II. RUSSIAN POPULATION ${ }^{\mathrm{e}}$ IN JEWISH WARDS

$\begin{array}{crr}\text { Ward } & 1890^{\mathrm{b}} & 1910^{\mathrm{c}} \\ 7 & 16,295 & 46,036 \\ 10 & 30,476 & 70,341 \\ 11 & 3,149 & 2,921 \\ 13 & 13,190 & 14,549\end{array}$

TABLE III. POPULATION PER ACRE AND NUMBER OF ACRES IN JEWISH WARDS

$\begin{array}{cccccc}\text { Ward } & \text { No. of Acres } & 1880^{\mathrm{a}} & 1890^{\mathrm{c}} & 1900^{\mathrm{c}} & 1910^{\mathrm{a}} \\ 7 & 166 & 252.9 & 289.7 & 478.1 & 495.6 \\ 10 & 98 & 432.3 & 523.6 & 653.5 & 609.5 \\ 11 & 165 & 350.9 & 384.8 & 515.3 & 641.0 \\ 13 & 160 & 352.2 & 428.8 & 599.2 & 593.1\end{array}$

TABLE IV. RANK ACCORDING TO DENSITY OF JEWISH WARDS AMONG THE 22 WARDS OF MANHATTAN

$\begin{array}{ccccc}\text { Ward } & 1880^{\mathrm{a}} & 1890^{\mathrm{c}} & 1900^{\mathrm{c}} & 1910^{\mathrm{a}} \\ 7 & 6 & 6 & 4 & 5 \\ 10 & 1 & 1 & 1 & 3 \\ 11 & 3 & 3 & 3 & 2 \\ 13 & 2 & 2 & 2 & 4\end{array}$

\footnotetext{
a John Shaw Billings, Vital statistics of New York and Brooklyn, 1890, pp. 230, 235.

${ }^{\mathrm{b}}$ Charity Organization Society, $A$ handbook on the prevention of tuberculosis (Lilian Brandt), 1903, p. 85.

c1910 statistics for corresponding assembly districts, 13th census, vol. 3, pp. 523-524.

${ }^{\mathrm{d}}$ Maurice Fishberg, American medicine, 2 November 1901, p. 697.

"'Russian population" was considered to be Jewish according to the census authorities.

${ }^{23}$ Anzia Yezierska, Salome of the tenements, New York, Boni \& Liverwright, 1923, pp. 9-14.

${ }^{24}$ New York Times, 18 January 1895, reprinted in Allan Schoener, Portal to America, New York, Holt, Rhinehart \& Winston, 1967, p. 212.
} 
In 1905, there were 115 blocks on the Lower East Side with an average density of 750 or more persons per acre, and 39 with a density of 1,000 or more per acre..$^{25}$ In Manhattan in the early years of this century, 70 per cent of all workers engaged in manufacturing, 67 per cent of the factories, and 28 per cent of the city's inhabitants were located below 14th Street on 1/100 of the city's land area ${ }^{26}$ Furthermore, the Lower East Side had only 29.8 acres of park space, or 2 per cent of the city's total park area. ${ }^{27}$

There was an astounding variety of activity in the Lower East Side. The University Settlement Report of 1896 included a social census of the tenth ward. There were 989 tenement houses; eight public schools; three theatres, with a total seating capacity of 9,500; sixteen stables, with a capacity of 210 ; thirteen pawn shops; seventy-two restaurants; forty-one churches, of which thirty-one were synagogues; sixty-five factories; 172 garment makers' shops; 236 saloons, of which 108 were Raines Law Hotels, a combination saloon and brothel of the seediest type; and eighteen "Disorderly Places". There were thirty-four bathtubs; four in private houses, twelve in barber shops, and eighteen in lodging houses. ${ }^{28}$ In 1904 David Blaustein, Superintendent of the Educational Alliance, took a private census of approximately thirty-two streets south of Houston Street and east of the Bowery. He found 5,007 tenements housing 64,268 families engaged in eighty-four different occupations. There were 306 synagogues, and so few public schools in comparison to need that the children could only attend half-day sessions. ${ }^{29}$

The Lower East Side also had a burgeoning red light district centred on Allen Street. As the neighbourhood became increasingly Jewish in character, the saloons moved out; Jews were temperate, and business became slack. The red light district, by contrast, became more prominent. Allen Street was not simply a spectacle in the ghetto. It was part of the way of life of the poor. Michael Gold, an active Communist, remembers the neighbourhood in which he grew up:

The East Side of New York was then the city's red light district, a vast 606 playground under the business management of Tammany Hall.... There were hundreds of prostitutes on my street. They occupied vacant stores, they crowded into flats and apartments in all the tenements.... On sun-shiny days the whores sat on chairs along the sidewalks. They sprawled indolently, their legs taking up half the pavements. People stumbled over a gauntlet of whores' meaty legs.... Earth's trees, grass, flowers could not grow on my street; but the rose of syphilis bloomed by night and by day. ${ }^{30}$

\section{IV}

Living conditions for the families of the Lower East Side were dictated largely by the conditions of their homes. The tenements, in turn, were fundamental to the health conditions of Lower East Side inhabitants. Legally, "tenement house" was defined in

${ }^{25}$ Harold Finley, 'The congestion of Manhattan', Federation, 1908, 5: 17-18.

${ }^{26}$ (a) Manufacturing and land area: Edward E. Pratt, Industrial causes of congestion of population in New York City, New York, Columbia University, 1911, p. 42. (b) Population figure: Finley, op. cit., note 25 above, p. 16.

${ }^{27}$ Ibid.

${ }^{23}$ Annual report of the University Settlement Society, 1896, p. 10.

${ }^{29}$ Miriam Blaustein, Memoirs of David Blaustein, New York, McBride, Nast, 1913, pp. 138-139.

${ }^{30}$ Michael Gold, Jews without money, New York, Horace Liverwright, 1930, pp. 14-15. 


\section{Deborah Dwork}

1867 as, "any house, building ... occupied as the home or residence of more than three families living independently of one another, and doing their own cooking on the premises, or by more than two families upon a floor, so living and cooking and having a common right in the halls, stairways, yards, water-closets, or privies, or some of them. ..."31 This definition could also suit flats and apartment houses, which were not then or now known as tenements. Jacob Riis, an ardent reformer and pioneer photographer-journalist, described the tenement:

It is generally a brick building from four to six storeys high on the street, frequently with a store on the first floor which, when used for the sale of liquor, has a side opening for the benefit of the inmates and to evade the Sunday law; four families occupy each floor, and a set of rooms consists of one or two dark closets, used as bedrooms, with a living room twelve feet by ten. The staircase is too often a dark well in the centre of the house, and no direct ventilation is possible.... ${ }^{32}$

The immigrants' descriptions were more pithy, if less precise. "Our tenement was nothing but a junk-heap of rotten lumber and brick.... The plaster was always falling down, the stairs broken and dirty. ... There was no drinking water in the tenement for days." 33 "The bedbugs lived and bred in the rotten walls of the tenement, with the rats, fleas, roaches. ...."34"In America were rooms without sunlight." 35

The number of houses without light, ventilation, hot running water, baths, or water closets was overwhelming. In 1900, the Tenement House Committee of the Charity Organization Society illustrated this problem by exhibiting a cardboard model of an entire block. The chosen block, bounded by Chrystie, Forsyth, Canal, and Bayard Streets, was in the tenth ward. The 80,000 square foot area boasted thirty-nine tenement houses (nearly all six storeys high) with 605 apartments. These buildings housed 2,781 people, 2,315 over five years of age and 466 under five. There were 264 water closets; only forty apartments had hot water. The one bathtub on the block, wedged in an air shaft, was obviously unusable. Of the total 1,588 rooms, 441 or 27.7 per cent were completely dark, with no access to outer air; 635 rooms or 40 per cent were ventilated only by dark, narrow air shafts. The rent roll was high, at $\$ 113,964$ a year. The disease toll was also high. During the preceding year (1899), thirteen cases of diphtheria had been reported to the Health Department; during the past five years (1895-1900), thirty-two cases of tuberculosis had been reported. ${ }^{36}$ It was estimated that "not over two-thirds of the cases are actually reported to the department." 37 Startling as they may seem, these conditions were by no means unique. Table $\mathrm{V}$ illustrates that the block was typical.

The tenement house was not a new invention at the turn of the century, manufactured to accommodate the late mass immigrations. Tenement houses had been a social, political, and health problem in New York City since the early 1800s.

\footnotetext{
${ }^{31}$ L. Veiller and R. De Forest (editors), The tenement house problem, vol. I, New York, Macmillan, 1903, p. 94.

32 Jacob Riis, How the other half lives, New York, Hill \& Wong, 1957, pp. 13-14.

${ }^{33}$ Gold, op. cit., note 30 above, p. 248.

34 Ibid., p. 72.

3s Yezierska, op. cit., note 7 above, p. 264.

${ }^{36}$ (a) Veiller and De Forest, op. cit., note 31 above, p. 113. (b) Jacob Riis, The peril and preservation of the home, Philadelphia, George W. Jacobs, 1903, pp. 126-127.

${ }^{37}$ Veiller and De Forest, op. cit., note 31 above, p. 449.
} 
Health conditions of immigrant Jews on the Lower East Side of New York: 1880-1914

\begin{tabular}{lcccc} 
TABLE V. & HOUSING STATISTICS OF THE JEWISH & \multicolumn{4}{c}{ WARDS OF NEW YORK CITY, } & Y & Ward 7 & Ward 10 & Ward 11 & Ward 13 \\
Description & 206 & 109 & 213 & 109 \\
Acres & 1,500 & 1,179 & 2,031 & 1,123 \\
Tenement houses & 0 & 142 & 182 & 114 \\
Rear buildings & 17,597 & 15,313 & 21,771 & 13,195 \\
Apartments & 852 & 181 & 1,468 & 755 \\
Vacant apartments & 4.8 & 1.1 & 6.7 & 5.7 \\
\% Vacant apartments & 16,745 & 15,132 & 20,303 & 12,440 \\
Families & 72,446 & 76,073 & 89,361 & 55,564 \\
Population in tenement houses & 11,473 & 10,633 & 14,058 & 9,414 \\
Children < 5 years & 0 & 3 & 28 & 0 \\
Tenement houses 7 storeys & 13 & 198 & 251 & 105 \\
Tenement houses 6 storeys & 1,049 & 678 & 694 & 501 \\
Tenement houses 5 storeys & 245 & 179 & 801 & 218 \\
Tenement houses 4 storeys & 173 & 110 & 237 & 266 \\
Tenement houses 3 storeys & 1 & 0 & 5 & 4 \\
Tenement houses 2 storeys & & &
\end{tabular}

a'Lawrence Veiller, 'A statistical study of New York's tenement houses', The tenement house problem, Vol. I, (Veiller and De Forest, eds.), New York, Macmillan, 1903, pp. 199-204.

Public action, however, was not taken until the middle of the century. In 1842, Dr. John H. Griscom, a city inspector of the State Board of Health, drew attention to tenement house conditions and urged that legislative action be taken to ameliorate the situation. Although this was not done, in 1846 The New York Association for Improving the Condition of the Poor (AICP) began investigating slum conditions. An 1854 report disclosed the startling extent of poverty and disease which the AICP had found, and prodded the public conscience by stressing the great need for reform. As a result of this report, the State Legislature appointed a Commission to study the tenement situation and to propose ameliorative legislation. However, in 1857, the Legislature turned down the Commission's reform bill.

Public interest waned until the draft riots of 1863 and high death rates stimulated a group of prominent New Yorkers to form a Citizens' Association. A sub-committee on sanitary conditions, the Council of Hygiene and Public Health, included eminent physicians. Despite the Council's reports on the loathsome sanitary conditions of New York City, the State Legislature still did not act. Finally, in 1865, after cholera appeared in Europe, fear of an epidemic in New York convinced the Legislature to establish a Metropolitan Board of Health for New York City (1866), and a Tenement House Law (1867). ${ }^{* 38}$

The fact that these measures were passed at all was highly significant. It demonstrated the development of a legal consciousness of the importance of the public health. With the Tenement House Law, society recognized the right to limit the entrepreneurial freedom of builders in the interest of public health. However, the law itself was vague, and standards were low. Most requirements could be altered at the discretion of the Board of Health; and the requirements themselves were not sufficient

\footnotetext{
* At this time there were approximately 15,000 tenements in the city.

38 Information on the history of tenement house reform, 1834-1867: (a) Veiller and De Forest, op. cit., note 31 above, pp. 71-97; (b), Roy Lubove, The progressives and the slums, Pittsburgh, University of Pittsburgh Press, 1962, pp. 1-28; (c) Roy Lubove, 'The New York Association for Improving the Conditions of the Poor: the formative years', N.Y. hist. Quart. 1959, pp. 307-327.
} 


\section{Deborah Dwork}

to protect the inhabitants. Among the major provisions: tenements had to have fire escapes or some other means of egress; a water tap had to be furnished either indoors or outside. Only one water closet or privy had to be provided for each twenty inhabitants, and it could be located outdoors (usually in the rear yard). Water closets and privies had to connect with sewers, but only if such existed. Cesspools were forbidden, except where necessary. There was no limit on the percentage of the lot which the building might cover. ${ }^{39}$

In 1879, the history of the tenements took a sharp turn. During December of the previous year, editor Charles F. Wingate held a $\$ 500$ competition in Henry C. Mayer's new trade journal, the Plumber and Sanitary Engineer. The competition, entitled "Improved Homes for Workingmen" or "The Model Home Competition", called for erection on a standard city lot $(25 \times 100$ feet $)$ of a brick building which provided "security against conflagration (including fireproof staircases open to the air), distribution of light, ventilation, drainage and other sanitary appointments ... inexpensiveness." 40

James E. Ware won first prize; his construction, commonly known as the "dumbbell" or "double-decker" tenement (Fig. 3), was published in March 1879. Despite the magazine's exhortations that "it is irrational to suppose that a commodious and healthful house for a large number of families can be built upon an ordinary lot $25 \times$ 100 " 41 and that "the present competition has demonstrated that stringent restrictions should be made upon the erection of houses of this class," 42 the dumb-bell tenement was mass-produced for the working class in New York between 1879 and 1901.*43

- The competition stimulated public interest in tenement house reform. On Tenement House Sunday (23 February 1879), concerned New York clergy preached on the subject. On 28 February, at Cooper's Union, Mayor Cooper presided over a large public meeting, again dealing with tenement house reform. Within days, the Mayor's Committee of Nine was formed with a mandate to devise reform measures.

\footnotetext{
39 Veiller and De Forest, op. cit., note 31 above, pp. 71-92. Lubove, op. cit., note 38b above, pp. 1-28.

40 'Improved homes for working men', Plumber and Sanitary Engineer, December 1878, pp. 1, 32.

41 Ibid., 1879, 2: 89.

42 Ibid.

* The dumb-bell tenement was a brick structure five to seven storeys high, 25 feet wide, and 75 to 90 feet deep. It merely modified the old system of dividing the lot into front and rear buildings by connecting the front to the rear with a narrow hall. The two front ground-floor apartments were generally stores in front with living rooms behind. Between them ran the entrance hallway, less than three feet wide, more than 60 feet deep, and almost totally dark. The staircase was located approximately 50 feet back. Opposite the stairway were two water closets, each ventilated by the air shaft and each shared by two families. Sometimes a dumb waiter was provided between them. Each floor contained four apartments or fourteen rooms. seven on each side of the hallway, running straight back along the hallway. The front apartment consisted of four rooms, the rear apartments of three. The largest room was the front parlour, which measured $10 \frac{1}{2}$ by 11 feet; bedrooms measured 7 by $8 \frac{1}{2}$ feet. Only four of the fourteen rooms received direct light. The rest were supposed to be illuminated by the air shaft, an enclosed indentation in the side of the building which measured 28 inches by 50 to 60 feet and as tall as the building itself. ${ }^{44}$ At the turn of the century, the rent for a front apartment was about $\$ 15$ a month, that of a rear apartment $\$ 11-12.45$

${ }^{43}$ Lubove, op. cit., note 38 b above, p. 31.

4 Information on the dumb-bell: (a) Veiller and De Forest, op. cit., note 31 above, pp. xiv, 8-9; (b) Lubove, op. cit., note 38b above, pp. 31-32; (c) Plumber and Sanitary Engineer, op. cit., note 41 above, pp. 90-91.

4s Annual report for the University Settlement Society, 1899, p. 20.
} 
Approximately one month later, it introduced a successful bill amending the Tenement House Law of 1867 . While the bill modified various regulations of the preceding law and provided for thirty sanitary police to enforce the housing code, it still subjected all requirements to the discretionary power of the Board of Health. It did, however, limit the percentage of space a new building could occupy to 65 per cent of the lot, and required a window measuring a minimum of twelve square feet in rooms used for sleeping.

There was no new legislation or important public agitation until 1884, when Professor Felix Adler, founder of the Society for Ethical Culture, again roused public interest and energy with a series of lectures decrying the tenement blight. This renewed public concern forced the Legislature to appoint a second legislative Commission, whose recommendations stimulated the passage of further amendments to the Tenement House Law in 1887. The number of sanitary police was increased to forty-five. Running water on every floor and one water closet per fifteen inhabitants were now required. The Board also took responsibility for inspecting every tenement semi-annually.

The mayoral Tenement House Commissions of 1894 and 1900 produced further landmarks of tenement house reform. The 1894 Commission was created due to public anger caused by series of exposés published by a newspaper, the Press. The resulting Tenement House Law of 1895 provided for two small parks on the Lower East Side and five recreation piers to be built along the river.

The Commission of 1900 grew out of interest stimulated by the Charity Organization Society's (COS) Tenement House Committee exhibit. Lawrence Veiller, who directed this Committee, was appointed secretary of the Commission. Its recommendations, adopted in their entirety in 1901, prohibited the future erection of dumbbell type tenements. In new construction, the space between buildings was to be enlarged from an air shaft to a court. A separate water closet had to be installed in each apartment. ${ }^{46}$ Although baths were not required, an inspection of 311 new tenement houses revealed that 125 of them, or 40 per cent, had a private bath for each apartment. Veiller also reported that many landlords voluntarily improved the plumbing on their property. Clearly, the tenement population desired toilets, sinks with running water, and baths, and were willing to repay the landlord for his investment through increased rent. ${ }^{47}$

Unfortunately, at least initially, the majority of Jewish immigrants were not in a position to take advantage of the major innovations of the 1901 law. For example, the tenth ward had been built up during the last decades of the nineteenth century, and by 1901 little land was left for new construction. The few new apartments built after 1901 were in great demand, especially by those immigrants who had been in New York for a number of years and could afford the luxury. Often, the apartments were rented even before they were completed..$^{48}$

\footnotetext{
46 Information on the history of tenement house reform, 1868-1901: (a) Veiller and De Forest, op. cit., note 31 above, pp. 98-115; (b) Lubove, op. cit., note 38b above, pp. 28-33, 81-149.

47 Veiller and De Forest, op. cit., note 31 above, p. 47.

48 Cahan, op. cit., note 11 above, p. 250.
} 


\section{Deborah Dwork}

In existing tenements, landlords were required by the 1901 law to install a window in any room which had none. School sinks (sewer-connected privies) and privy vaults had to be replaced with individual water closets. The Commission also detailed specifications for fire-proofing, fire-escapes, and the lighting of public hallways of existing and future tenements. These measures to safeguard the public health were influenced by contemporary medical knowledge. The bacteriological origins of disease set forth by Koch and Pasteur in the 1870s were by this time becoming popularly understood and accepted. The importance of sunlight and ventilation in destroying the tubercle bacillus was stressed in the Commission's report.49

As Table V shows, within the Jewish wards the dumb-bell tenement was the predominant housing structure, and there were a significant number of rear buildings as well..$^{50}$ The latter were built prior to 1879 and, without direct access to the street, were less well ventilated and sunlit, and more of a fire hazard than the dumb-bell tenement. The dumb-bell structure, built between 1879 and 1901, was characterized by an air shaft which was supposed to provide light and air to the rear rooms. In fact, the air shaft was as much a hazard as a convenience. It conveyed noise and odours, and acted like a huge flue in a fire. According to Jacob Riis, "more than half of all fires in New York occur in tenement houses," and the air shaft, functioning like a chimney, "added enormously to the fireman's work and risk." 51 The air shaft also served as a garbage dump, and, consequently, was even more infested with rats and vermin than the other parts of the tenement structure. Statistics prove that landlords were slow to comply with the 1901 window requirements, designed to succeed where the air shaft had failed in providing light and air. There were 350,000 dark interior rooms in Manhattan in $1902 . .^{32}$ In 1908 , there were still 300,000 south of Houston Street alone..$^{33}$

Tenement houses were not just inadequate, unsanitary homes - they were also inadequate, unsanitary work sites. It was not possible to separate "workshop" from "living quarters" among immigrant Jews.

Let us follow one [immigrant man] to his home and see how Sunday passes in a Ludlow Street tenement.

Up two flights of stairs, three, four, with new smells of cabbage, of onions, of frying fish, on every landing, whirring sewing machines behind closed doors betraying what goes on within, to the door that opens to admit the bundle [of unfinished garments] and the man. A sweater, this, in a small way. Five men and a woman, two young girls, not fifteen, and a boy who says unasked that he is fifteen and lies in saying it, are at the machines sewing knickerbockers, "knee-pants" in the Ludlow Street dialect. The floor is littered ankle-deep with half-sewn garments. In the alcove, on a couch of many dozens of "pants" ready for the finisher, a bare legged baby with pinched face is asleep. A fence of piled-up clothing keeps him from rolling off on the floor. The faces, hands, and arms to the elbows of everyone in the room are black with the colour of the cloth on which they are working. ... .

They are "learners," all of them, says the woman ... and have "come over" only a few weeks ago."54

\footnotetext{
4 Hermann M. Biggs, 'Tuberculosis and-the tenement house problem', and Arthur R. Guerard, 'The relation of tuberculosis to the tenement house problem', in Veiller and De Forest (editors), op. cit., note 31 above.

so Ibid., vol. 2, p. 87.

s1 Jacob Riis, Children of the tenement, New York, Macmillan, 1903, pp. 252-253.

32 Veiller and De Forest, op. cit., note 31 above, p. xvii.

s3 Claude H. Miller, 'The menace of crowded cities', World's Work, 1908, 16: 10269.

s4 $R$ iis, op. cit., note 32 above, pp. 92-93.
} 
$\mathrm{V}$

The immigrants arriving in New York found employment wherever they could. "Everyone grabbed the type of job he could get, and changed it very often.... Today, one can be a shoemaker; tomorrow, a tailor, and the day after tomorrow he is forced to become a farmer; later a bookkeeper and so on ad infinitum," wrote George Price. ${ }^{s s}$ Price himself worked in six different types of factories, taught, did manual labour, worked in ditches and on trains, and finally became a prominent physician in the trade union movement.

The majority of immigrant Jews found work in the needle trades shortly after arrival. Tailoring was easy to learn and was not physically demanding - an excellent combination for the immigrants. Some were snatched up by a contractor at Castle Garden or Ellis Island. Many others entered the needle trades following the example of family or friends who had preceded them. By and large they sought employment among other Jews. This enabled them to observe religious law and eliminated a formidable language barrier. An 1890 survey by the Baron de Hirsch Fund found that 14,316 or 55 per cent of the employed permanent residents of wards 7,10 , and 13 , worked as tailors, cloakmakers, and labourers in white goods and other branches of the needle trades. There were also 452 furriers and 309 dealers in clothing. Peddling, the second most common occupation, employed another 9.3 per cent or 2,440 people. The survey found 1,382 clerks, 976 cigar-makers, 633 shoemakers, and 500 who owned tailor stores. ${ }^{36}$ By 1897 , according to the 12th Annual Report of the Factory Inspector of New York, 75 per cent of the 66,500 workers in the clothing industry in Manhattan ${ }^{37}$ and 80 per cent of the 15,000 cloakmakers were Jewish..$^{88}$ Manhattan was rapidly becoming the hub of the industry; by 1905, half of the clothing manufactured in the United States was produced in New York. ${ }^{59}$ The predominance of Jews in the needle trades continued well into the closing years of our study. The fur trade in 1910 was 75 per cent Jewish. ${ }^{60}$ In 1911, the Joint Board of Sanitary Control in the Cloak, Suit and Skirt Industry reported that 85-90 per cent of its workers were Jewish. ${ }^{61}$ The dress and waist industry reported in 1913 that 77.7 per cent of its workers were female, and that 56.16 per cent of these women were Jewish. ${ }^{62}$

By the late nineteenth century, the needle industry in New York was also overwhelmingly owned and operated by Jews. Historically, Jews had always been involved in the clothing industry. Christians in the United States had allowed Jews to deal in second-hand clothing because this was considered a despicable occupation. ${ }^{63}$ This

\footnotetext{
ss Price, op. cit., note 22 above, p. 47.

${ }^{36}$ Lloyd P. Gartner, 'The Jews of New York's east side, 1890-1893', Amer. Jew. hist. Quart., March 1964, pp. 268-272.

${ }^{37}$ Twelfth annual report of the Factory Inspector of the State of New York (1897), published 1898, p. 45.

ss Judith Greenfield, 'The role of the Jews in the development of the clothing industry in the United States', YIVO Ann. of Jew. Soc. Sci., 1947, 2: 187-188.

s9 Pratt, op. cit., note 26a above, p. 80.

${ }^{60}$ Rischin, op. cit., note 4 above, p. 66.

${ }^{61}$ First annual report of the Joint Board of Sanitary Control in the Cloak, Suit, and Skirt Industry of Greater New York, New York, October 1911, p. 39.

62 Joint Board of Sanitary Control in the Dress and Waist Industry, Special report on sanitary conditions in the shops of the dress and waist industry, May 1913, p. 7.

${ }^{63}$ Jesse E. Pope, The clothing industry in New York, University of Missouri, 1905, p. 1.
} 


\section{Deborah Dwork}

traditional foothold in the clothing industry enabled Jews to take advantage of its fantastic growth during the second half of the nineteenth century.

Three factors greatly stimulated this growth: the Civil War created an unprecedented demand for mass-produced uniforms, the invention of the sewing machine in 1846 provided a means of manufacture, and the large influx of Irish and, later, German immigrants during the mid-century provided the labour force. After the Civil War, the demand for uniforms decreased, but the industry created a consumer market by providing fashionable clothing at much lower cost than custom tailoring. Until the early 1880 s skilled German tailors and Irish cutters controlled production. ${ }^{64}$ Then competition arrived in the form of Eastern European Jews who had spent time in London learning not only the tailor's craft but also English language and customs. These tailors broke into the production business and paved the way for future immigrants. The clothing industry thus became one of the few in which Jews were employers. ${ }^{65}$

Within the American needle industry, there were three systems and three sites of production. Most antiquated was the so-called "family system", which had become the dominant system of production under German immigrant influence in the midnineteenth century. Irish tailors worked in shops, but the Germans worked at home, dividing the labour among family members. Usually the husband was the most skilled worker, the master tailor. He operated the sewing machine while his wife and children did the basting, buttonholes, and finishing touches. This "homework" was done in the family's tenement apartment.

The contracting or "sweat-shop" system grew out of the family system. As competition and the volume of work increased, much time had to be spent obtaining work to do; picking up the cloth or, more commonly, pre-cut, unsewn garments; and then delivering the completed product to the warehouse. Enter the contractor. He knew English and had lived in America at least longer than the greenhorns. He contracted with the manufacturer to do $\mathrm{X}$ work for $\mathrm{Y}$ price by $\mathrm{Z}$ date, and was then free to conduct his business as he chose. This seemed ideal to newly arrived immigrants; they could communicate in their own language, observe the Sabbath on Saturday, and maintain other religious laws.

There were a few variants to the contracting system. The contractor could act as a middleman between the working family and the manufacturer, or hire labourers of his own (who would also work in the tenement, either in the contractor's own apartment, or one rented for work purposes), or he could sell the job to a sub-contractor who performed the same function as the contractor himself. Until the last decade of the nineteenth century, the cloak, suit; and skirt trade was primarily controlled by these petty manufacturers. One estimate ascribed 90 per cent of all ladies' coats and suits produced in New York City in 1890 to the contractor.66 Dr. George Price, by then chairman of the investigative committee of the Joint Board of Sanitary Control in the Cloak, Suit, and Skirt Industry, explained the proliferation of contractors. "Very

at Ibid., p. 27.

os Ibid., p. 49.

${ }^{60}$ Greenfield, op. cit., note 58 above, p. 191. 
little capital was needed for the establishment of a shop, as the workers were compelled to furnish their own machines, which were run with foot power. The workers were also often compelled to pay deposits for the privilege of work. All the enterprising manufacturer had to invest was his ability to get work, and perhaps capital enough to pay for the rent of his "factory'."67 These factories were located in lofts, tenement house apartments "converted" for industrial use, or in the tenement home itself. A "cockroach sweater" was the lowest man on the contractor totem pole; his was a small business with few employees, usually run in his own tenement apartment.

The third production site was the inside shop, in which the manufacturer dealt directly with the store buyer, hired his own workers, and ran his own factory. The manufacturer usually worked with a designer, who created fashions or imitated famous designs. The manufacturer displayed these models to the store buyer, who ordered them for the season.

As was generally the case in industry, the physical conditions in which garment workers laboured ranged from poor to foul. The lack of light, space, ventilation, plumbing, and sanitation in tenements has been described already. This situation was exacerbated by the use of the tenements for manufacture. Jacob Riis described the filth and penury over and over again in prose and with photographs. The third annual report (1888) of the New York factory inspectors also discussed the problem of Jewish homework. "They usually eat and sleep in the same room where the work is carried on, and the dinginess, squalor and filth surrounding them is abominable."68 (Fig. 4). Annie S. Daniel (1858-1944), an eloquent physician interested in the welfare of the poor and particularly concerned about public health, perceived the problem in 1904-5 from another standpoint:

These "homes" of working men and women consist of from two to four rooms. In one room, that which opens on the street or yard, is carried on all the domestic life. This room serves for parlor, dining-room, and kitchen; and in this room in addition is carried on the manufacturing. It is quite obvious that the word home was never intended to apply to such an apartment.... Every garment worn by a woman is found being manufactured in tenement rooms.... [Some] I have seen being made in the presence of small-pox, on the lounge with the patient.... Among the 150 families [I attended who did] manufacturing in the living rooms, 66 continued to work during the entire course of the contagious disease. ${ }^{69}$

Conditions in the sweatshops and most factories were equally abominable. In his memoirs, Gregory Weinstein describes a printshop of the 1880s: "Dark shops in rickety buildings; climbing up four, five and six flights of wooden stairs; cases full of dust and rat dirt; working under.gas-light from seven o'clock in the morning till six in the evening." 70 Nearly twenty years later, in 1903, conditions in the needle trades were just as bad. Yetta, the heroine of Arthur Bullard's roman-à-clef, Comrade Yetta, views her surroundings: "She saw the broken door to the shamefully filthy toilet, saw the closed, unwashed windows, which meant vitiated, tuberculosis-laden air, saw the backs of the women bent into unhealthy attitudes, saw the strained look in their eyes." 11

${ }^{67}$ First annual report of the Joint Board, op. cit., note 61 above, p. 35.

os Third annual report of the Factory Inspector of the State of New' York, 1888, published 1889, p. 27.

69 Annie Daniel, 'The wreck of the home', Charities, 1905, 14: 624-629.

${ }^{70}$ Gregory Weinstein, The ardent eighties, New York, International Press, 1928, p. 46.

" Arthur Bullard, Comrade Yetta, New York, Macmillan, 1913, p. 108. 


\section{Deborah Dwork}

By 1910, homework was in Italian immigrant hands; Jewish labour had moved into inside shops. ${ }^{22}$ Unfortunately, most workshops were not a great improvement. In 1910, inspection of 228 waist shops employing 11,000 workers showed that 62 per cent used inadequate artificial light, and 60 per cent provided no protection against the glare. Thirty per cent had filthy water closets with no light or ventilation, and in 28 per cent of the shops the general conditions were labelled "extremely dirty". ${ }^{33}$ Loft buildings housed 91 per cent of the inspected establishments, and over one-half of the employees worked above the sixth floor. ${ }^{74}$ This was basically the case in all branches of the needle trades. Loft buildings had improved sanitary conditions in the industry; they were new edifices with large windows providing natural illumination and ventilation, and had up-to-date plumbing facilities. But they posed a much greater fire hazard than previous work sites. Building materials were flammable, fire-escapes were either not provided or inadequate, and the loft buildings were simply too high - the Fire Department could not handle fires above the seventh floor. ${ }^{75}$ This dilemma was horribly illustrated by the famous fire at the Triangle Waist Company on 25 March 1911, which killed 146 employees.

A 1913 inspection of 700 dress and waist shops revealed that 97.3 per cent were located in loft buildings, 2.7 per cent in converted buildings, and none in tenements or cellars. The sanitary conditions of the loft buildings were considered very good, with only 5 per cent using artificial light and 3 per cent having no protection from glare. Only 4.5 per cent had dirty water closets. However, if anything, the danger from fire had increased, as there were now more people working at greater heights. A little over 50 per cent of those in the industry, or 18,417 persons worked on or above the sixth floor, and nearly 10 per cent, or 3,530 persons worked on or above the twelfth floor. The Fire Department was still incapable of handling fires at these heights, and only 7 per cent of the shops practised fire drills. Fifteen shops had no fire escapes; forty-seven had obstructed access to the fire-escape; and forty-six had no safe means to escape from the fire-escape, which meant that workers could be trapped in an enclosed courtyard or alley - a tunnel of fire (Fig. 5). A full 30 per cent of the shops had doors which opened inwards, making escape difficult and dangerous. Finally, as in the Triangle fire, a few employers still illegally locked their employees in the work room, making escape impossible. ${ }^{76}$

Similar conditions prevailed in the predominantly male cloak, suit, and skirt industry. ${ }^{* 1}$ After the great cloakmakers' strike in 1910, a Joint Board of Sanitary Control was established to study and ameliorate shop conditions. In 1911, the com-

72 (a) State of New York, Preliminary report of the Factory Investigating Commission, 1912, vol. III, Albany, Argus, p. 1766. (b) State of New York, Second report of the Factory Investigating Commission, 1913, vol. II, Albany, J. B. Lyon, p. 684.

${ }^{73}$ State of New York, op. cit., note 72a above, vol. I, p. 277.

74 Ibid.

75 First annual report of the Joint Board, op. cit., note 61 above, p. 49.

76 Joint Board of Sanitary Control, op. cit., note 62 above, pp. 10-13.

*In the five inspections prior to and including 1913, 77 per cent of the workers were male (while 77.7 per cent of the workers in the dress and waist industry were female). At this time the industry employed more than 60,000 people in 2,000 establishments, 90 per cent of which were located below 34th Street.

77 Ibid., p. 7. 
mittee of investigation published its report on 1,738 shops. ${ }^{78}$ Two-thirds were found deficient in fire protection and/or sanitary conditions. ${ }^{79}$ At a time when chewing tobacco was common and spitting was not considered impolite, over 99 per cent of the shops had no cuspidors (in direct opposition to the law), thus increasing the risk of tubercular infection. The legal limit of one water closet for every twenty-five persons was also largely ignored - some shops had only one water closet for eighty-five workers. Hot water, towels, and rubbish bins were nearly unheard of, and 6.8 per cent of the shops were poorly ventilated. Lunch was eaten in the shop room itself. As in the dress and waist industry, however, fire was by far a greater danger to the workers than were the poor sanitary conditions. Loft buildings housed 90 per cent of workers, 50 per cent between the sixth and twelfth floors. The interiors of the buildings were hazardous, and rapid escape difficult. The halls were narrow; there were only 1,951 stairways in 1,738 buildings. Thus, most shops had only one means of egress, built either of stone, which heated quickly and then crumbled when wetted, or of wood, which burned easily. The vast majority of shops ( 84 per cent) had only one fire-escape, often narrow, leading into an enclosed courtyard or alley.80

In 1911, the Joint Board of Sanitary Control adopted sanitary standards which included fire precaution and prevention regulations. Certificates were given to worthy shops. In February 1912, shops employing 40 per cent of the workers were so certified, and in September 1912, shops employing 61 per cent of the workers were found sanitary. By September 1913, 79 per cent of the workers were employed in certified shops. In May of the same year the Joint Board published an alphabetical list of approved establishments. ${ }^{81}$

Thus far, we have primarily examined the physical and sanitary conditions of two branches of the ladies' garment industry. While the great majority of Jewish immigrants were industrial workers, not all were employed in the clothing industry. Industrial conditions in general were on a par with those of the needle trades prior to the 1910 cloakmakers' strike and subsequent formation of the Joint Board of Sanitary Control. George Price, reporting in 1912 for the Factory Investigating Commission (which had been established in response to the public's outcry after the Triangle fire), noted that 54 per cent of the shops had no, or insufficient, washing facilities, and an even larger percentage had no hot water. Few had lunch rooms; the great majority of workers ate in the work room. Poor toilet accommodations were the rule. Very few shops had emergency rooms or first aid facilities in case of illness or accident. The worst offender was the food industry, with baking, nutpicking, and ice cream manufacture commonly done in the tenement..$^{82}$

First annual report of the Joint Board, op. cit., note 61 above, p. 35.

" Lillian Wald, 'Sanitary control of an industry by the industry itself', Transactions of the fifteenth International Congress on Hygiene and Demography, vol. III, part II, Washington, D.C., Government Printing Office, 1913, p. 883.

- First annual report of the Joint Board, op. cit., note 61 above, pp. 64-68, 46-53.

"1 (a) George Price, 'Ten years of industrial sanitary self control', Tenth annual report of the Joint Board of Sanitary Control in the Cloak, Suit, and Skirt, and Dress and Waist Industries, New York, 1921, pp. 23, 27, 29. (b) Joint Board of Sanitary Control in the Cloak, Suit and Skirt Industry, Directory of certified shops, New York, May 1913.

22 State of New York, op. cit., note 72a above, vol. I, pp. 135-138, vol. II, pp. 87, 210. 


\section{Deborah Dwork}

Not only were the physical conditions of the workplace disgusting, degrading, and unhealthy, but the long hours and low wages increased the strain on the worker's constitution. Lillian Wald, founder of the Henry Street Settlement, wrote:

... from the windows of our tenement home we could look upon figures bent over the whirring footpower machines. One room in particular almost unnerved us. Never did we go to bed so late or rise so early that we saw the machines at rest, and the unpleasant conditions where manufacturing was carried on in the overcrowded rooms of the families we nursed disquieted us more than the disease we were trying to combat. ${ }^{33}$

It is impossible to discern exactly how many hours per day or week people worked. Hours differed from industry to industry, from "outside" shop to "inside" factory, and from rush to slack seasons. In 1891, New York factory inspectors reported a sixty-six- to seventy-two-hour minimum work week during the slack season in the clothing industry (if the worker were lucky enough to maintain his position), and sixteen to nineteen hours a day, seven days a week during the busy season. ${ }^{84} \mathrm{Dr}$. Annie Daniel reported women working at home nineteen hours a day, seven days a week during the busy season in 1904-5.85 Workers were hard put to decide which was worse: the anxiety and poverty of the slack season with little or no employment, or the hours and tension of the rush season with greater and greater work demands. Hours in the factories were slightly better. In 1894 the cloakmakers' union went on strike for - and won - a ten-hour day, reduced from the standard twelve to fifteen hours. In 1901 , nearly all clothing union workers sought a fifty-nine-hour week. ${ }^{86}$

Wages depended upon position, piece-work, sex, and whether the worker was employed by a contractor or in a factory. In all cases, wages were low, the difference being between poverty and penury. In 1888, male cloakmakers in inside shops earned an average weekly wage of $\$ 12 .{ }^{87}$ Annie Daniel reported that female homeworker wages averaged $\$ 1.04$ a week in 1904-5, and the average weekly income from the man's work was $\$ 3.81{ }^{88} \mathrm{Jacob}$ Riis gives various piece-work prices: there were knee-pants "for which the manufacturer pays seventy cents a dozen," or another grade of kneepants at 42c. a dozen. The finisher of the garment "gets ten and the ironer eight cents a dozen; button-holes are extra, at eight to ten cents a hundred." United States Industrial Reports, between 1880 and 1901 the weekly wage of New York coat-makers in task shops fell nearly 17 per cent. The work day increased by 20 per cent and productivity increased by 66 per cent. ${ }^{90}$ There were no significant technical advances during this period, nor any improvement in the division of labour. The workers simply worked harder and longer.

\section{VI}

Clearly, these abominable conditions - poorly lighted, filthy surroundings,

\footnotetext{
${ }^{83}$ Lillian Wald, The house on Henry Street, New York, Henry Holt, 1915, p. 281.

24 Pope, op. cit., note 63 above, p. 139.

${ }^{85}$ Daniel, op. cit., note 69 above, p. 625.

${ }^{86}$ Pope, op. cit., note 63 above, p. 140.

87 Ibid., p. 89.

Daniel, op. cit., note 69 above, pp. 625, 627.

29 Riis, op. cit., note 32 above, pp. 93,95 .

${ }^{90}$ Greenfield, op. cit., note 58 above, p. 202.
} 
incredibly low pay, and exceedingly long hours of repetitive work alternating with equally long seasons of unemployment - had a significant impact on the mental and physical health of the immigrant proletariat. However, before discussing the predicted and real effects of housing, work, and a new way of life on the immigrants, we must know their physical condition upon arrival. The immigrants who made their way to the Lower East Side of New York had already been medically examined two or three times. If they left Russia legally, they were examined at the border. They were further examined by the shipping companies prior to embarkation, and finally, by the medical authorities at Castle Garden or Ellis Island. On the average European Jews were $162.1 \mathrm{~cm}$. tall, with an arm span of $169.1 \mathrm{~cm}$. and a chest girth of $81 \mathrm{~cm}$. This made them the shortest and narrowest of all European peoples. ${ }^{91}$ In addition, Eastern European Jews had a poorly developed muscular system and were frequently anaemic. ${ }^{92}$ Thus, it is clear that they were not physically equipped for heavy manual labour; as we have seen, the majority of immigrants joined the industrial work force.

Good health was of the utmost importance for survival, and immigrants soon learned (if they did not already know) to dread the workshops as a cause and site of disease. Emma Goldman, who later became a political radical, worked in a corset factory in New York. After a few weeks, she found the strain unbearable, and wrote, "I suffered most from violent headaches." 93 Contemporary novels recognized curvature of the spine as an occupational hazard of needle workers. ${ }^{94}$ And tuberculosis was called "the tailors' disease". 95

For many years it had been understood in a general way that industry was carried on under conditions harmful to health. ${ }^{96}$ It was known, for example, that factory workers were more susceptible to disease than other workers; the death rate for males was 20.2 per 1,000 among the labouring and servant class in 1910, while it was 12.1 among the mercantile and trading class. ${ }^{97}$ It was also known that factory workers and the workers in tenements were more likely to contract tuberculosis than were persons otherwise employed. This was ascribed to malnutrition, lack of air and light, and congestion in the factory and at home. Ignorance about causes of and precautions against disease in general, and tuberculosis in particular, was also thought to be a primary factor in the high incidence rates. ${ }^{98}$

The fear of tuberculosis - "the shop sickness, the plague of Dollar Land"99 - figures large in the immigrant literature. However, it was some time before this fear was transformed into exploratory studies or ameliorative action. Until 1910 there were few or no formal demands by workers for improved sanitary conditions in the shop, although there was always a general complaint against them. The strike of 1910

\footnotetext{
91 Maurice Fishberg, 'Tuberculosis among the Jews', Amer. Med., 2 November 1901, p. 697.

${ }_{22}$ Charles Bernheimer, Half a century of community service, New York, Association Press, 1948, p. 283.

93 Emma Goldman, Living my life, Garden City, N.Y., Garden City Publishing Co., 1931, p. 37.

94 Bullard, op. cit., note 71 above, p. 12.

95 Wald, op. cit., note 83 above, p. 54.

96 State of New York, op. cit., note 72a above, vol. I, p. 141.

97 Ibid., p. 18.

98 Ibid., vol. II, p. 637.

99 S. B. Ornitz, Haunch, paunch and jowl, New York, Boni \& Liverwright, 1923, p. 43.
} 


\section{Deborah Dwork}

focused attention on the related problems of industrial sanitation, occupational hazards, and worker health. In the few years following the strike several studies were undertaken to assess these problems. "The best standard of the healthfulness or dangers of an industry would be a direct study of the physical conditions of its employees. ... Medical examinations of workers ... have been almost entirely neglected." 100

In 1911 the United Hebrew Trades, a conglomerate of eighty-six local Yiddishspeaking unions, requested that the Factory Investigating Commission medically examine the employees of the Furriers' Union, who worked under unusually poor conditions. Three-quarters of the fur shops were located in old tenement houses with wooden stairs, no ventilation, and no separate drying rooms - causing the work area to stink. Seventy per cent of the fur was dyed with what proved to be harmful chemicals, and the fur itself constituted a dust hazard. Conditions were so poor that many insurance companies would not sell policies to furriers. ${ }^{101}$

Eighty-three furriers were examined, 94 per cent of them male. Only 10.8 per cent were completely healthy; 89.2 per cent had one or more illnesses or unhealthy conditions. Catarrh (chronic rhinitis), and inflammation of the nasal mucous membrane caused by inhalation of dust and fur particles, afflicted 50.6 per cent of the furriers. Similarly, 30.1 per cent suffered from bronchitis, inflammation of the mucous membrane of the bronchial tubes. Another 25.3 per cent had some type of skin disease caused by dyes; 13.3 per cent had asthma, "a condition that is almost purely due to fur," 102 and which came to be known as "furrier's asthma". Six per cent had phthisis (pulmonary tuberculosis). ${ }^{103}$ In the medical examiner's opinion, "The sphere they labour in and the fact that their lungs are always irritated, both by the furs and the dust would tend to make them more susceptible to [phthisis] than if they were otherwise employed."104

In 1912 the Joint Board of Sanitary Control examined 800 cloakmakers in a similar study. While the percentage may have been considerably higher, at least 47.4 per cent of the examined workers can be safely classified as Jews. Only 37.3 per cent of the workers were healthy; 62.7 per cent suffered from one or more diseases. The examiners found that 21.7 per cent were anaemic, 6.4 per cent had eye problems, 7 per cent suffered from acute bronchitis, 21 per cent had a "digestive disorder" (disease of the pharynx, 13.2 per cent; stomach disease; 5.7 per cent; hernia, 2.1 per cent), and 1.6 per cent suffered from tailors' disease (phthisis). Syphilis and gonorrhoea were rare, with only one worker suffering from each. ${ }^{105}$

In 1911 George Price examined the health and working conditions of $800 \mathrm{New}$ York City bakers, at least one-third of whom were Jewish. Only 33 per cent of the Jewish workers were free of disease; the remaining 67 per cent suffered from one or

\footnotetext{
${ }^{100}$ George Price, 'Occupational diseases and the physical examination of workers', Transactions of the fifteenth International Congress on Hygiene and Demography, op. cit., note 79 above, p. 845.

101 State of New York, op. cit., note 72a above, vol. III, p. 1625.

102 Ibid., p. 1632.

${ }^{103}$ State of New York, op. cit., note 72b above, vol. II, p. 422.

104 Ibid., vol. III, p. 1632.

${ }^{105}$ Wald, op. cit., note 79 above, pp. 887-888.
} 
more illnesses. Among the Jewish workers, 28.5 per cent were anaemic; 23 per cent suffered from bronchitis, perhaps due to, and probably exacerbated by, the high temperature and humidity and the generally poor ventilation of the workshop. Eye infections, which afflicted 16.5 per cent of the workers, were ascribed to working in an artificially lighted, dusty cellar, in front of an oven. "Baker's itch", a distinctly occupational disease, and other skin ailments affected 7.6 per cent. Another 6.8 per cent had cardiac problems, 10 per cent had flat feet, there were two cases of venereal disease, and 2.8 per cent had tuberculosis. Price concluded that morbidity and mortality were "affected by the general conditions under which the work of a baker is carried on, including excessive hours, unsanitary conditions of bake shops, night work, etc." 106

The most comprehensive occupational health study was conducted in 1913 by J. W. Schereschewsky of the United States Public Health Service. Approximately 3,000 workers of the cloak, suit, and skirt, and dress and waist industries were examined. About two-thirds of the subjects were male and 96.7 per cent of the males were Jewish. They averaged 64.5 inches in height and 140 pounds in weight; 90 per cent were between twenty and forty years old. Only 15.5 per cent showed signs of poor nutrition, but only 29.5 per cent were physically well developed. Of the female workers, 88.8 per cent were Jewish. Because it was common for Jewish women to work only prior to marriage, their average age was considerably younger than the men's, with 92 per cent under thirty years old. In general they were better physically developed than the men, and appeared to be well nourished; 83 per cent were between 57 and 63 inches tall, and the average weight was 120 pounds. ${ }^{107}$

Only about 2 per cent of the examined workers were free of defects or disease. ${ }^{108}$ Anaemia was found in 4.6 per cent of the males and 11.9 per cent of the females; 13.4 per cent of the males and 6.5 per cent of the females had defective hearing. About 7 per cent of the total population suffered from chronic catarrhal or suppurative middle-ear disease. These percentages were considered higher than those occurring in the general population; they were attributed to exposure to continuous noise* and to the catarrhal conditions of the nose and throat commonly seen in garment workers. Rhinitis was found in 29.3 per cent of the males and 19.8 per cent of the females, and chronic bronchitis in 3.9 per cent of the males and 1.1 per cent of the females. One-quarter of the sample suffered from chronic constipation, one-quarter from defective teeth, and nearly three-quarters from defective vision (only 11.7 per cent of these wore glasses, and only 20 per cent of the bespectacled had their vision corrected). Half the men and one-fifth of the women had some degree of spinal curvature ("it was a rather rare circumstance to encounter a spine completely

\footnotetext{
${ }^{106}$ State of New York, op. cit., note 72a above, vol. I, pp. 228, 232.

107 J. W. Schereschewsky, 'The health of garment workers', Publ. Hlth Bull., May 1915, 71: 28-30, 46-48.

100 Ibid., p. 94.

*Immigrant memoirs, oral histories, and novels evoke the same image of the work place: "It was gehenna [hell], so noisy, all the clakety-clack of the machines. You couldn't hear yourself think, and you had to shout to the people next to you." 109

${ }^{109}$ Oral History, Mrs. D., now living in the Bronx, New York.
} 


\section{Deborah Dwork}

straight") and/or faulty posture. ${ }^{110}$ The most important and serious disease from which garment workers suffered was tuberculosis, with 3.1 per cent of the men and 0.9 per cent of the women actively tubercular. An additional twenty-nine persons were suspected of having tuberculosis, and many more had had it previously. The men's rate was ten times that of the United States Army, and the women's was nearly three times as great. It must be remembered that, on average the men were ten years older than the women, and had worked in the industry twice as long. ${ }^{111}$

The examiner reported that "no class of disorders peculiar to the garment trades was found, or which would not probably be found with like frequency in similar groups of workers engaged in sedentary, indoor occupations."112 Yet, "while the garment trades in themselves did not necessarily induce faulty postures, provided the postural habits of the worker were originally correct, occupation in the garment trades had a strong tendency to intensify incorrect postural habits." 113 The report acknowledged that garment workers' constant inhalation of the airborne particles or "fly" from cloth predisposed them to developing tuberculosis. ${ }^{114}$ In addition to physical ills, 10 per cent of the male workers and 3.2 per cent of the females suffered from neurasthenia or other psychological disorders. A considerably larger number "gave a strong impression of being predisposed to neuropathic affections."'115

The peculiar nature of the clothing industry affected mental health. One person, known as the "speeder", set the work pace. The heroine of Comrade Yetta described another woman, who had been the speeder for her task force but could no longer keep up:

She had entered the trade strong and healthy and had been well-paid at first, when she had the great desideratum - Speed. It had seemed like good pay then. But now she knew better. They had been buying not only her day-by-day ability, they had bought up her future. For the wages of less than ten years they had bought all her life. ${ }^{116}$

The seasonal nature of the work also endangered mental health. Less than 18 per cent of the workers studied by Schereschewsky were employed year round. ${ }^{117}$ "When there is work in the clothing factory, the short seasonal, body-destroying rush, he sits at his sewing machine ... twelve hours, fourteen hours, and thinks nothing of a twenty hour stint."118 "There are two factors ... which tend to cause over-strain . . the temptation to overspeed for the purpose of earning high wages when work is brisk, followed by a period of inactivity in the slack season, during which time is afforded for introspection, consideration of the future, worry as to whether work will be forthcoming during the next season, depression over the present bad season. . .."119

Work was not the only predisposing factor to disease. The deplorable conditions of

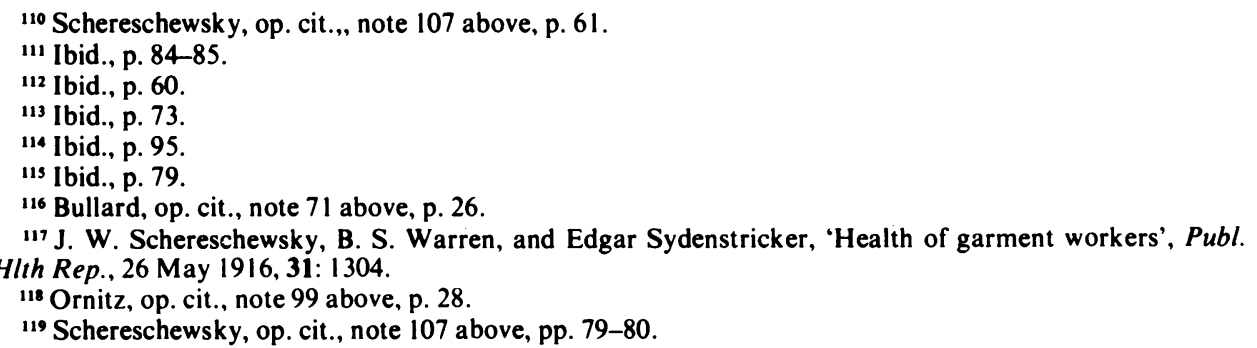


the tenements in which immigrant Jews lived determined their health as well. There are no statistics on accidents due to unlit or dimly lit tenement halls, rotten stairs, and lack of gratings on low windows. The immigrant literature, and case studies by settlement workers ${ }^{120}$ and reporters like Jacob Riis ${ }^{121}$ who were interested in social reform, lead to the inevitable conclusion that such accidents did occur.

There is better information about the relationship between housing and infectious diseases, especially tuberculosis and diphtheria. The discovery of the cause of tuberculosis led the New York City Department of Health to investigate the effect of living conditions on the incidence of the disease. Beginning in $1894 \mathrm{Dr}$. Hermann N. Biggs of the Department of Health mapped all reported tuberculosis deaths in Manhattan and Brooklyn, by date and house. ${ }^{122}$ The patterns of cases showed that the houses themselves became infected. Consumptive tenants expectorated sputum which contained virulent bacilli. When the sputum was not properly disposed of, it dried into dust, was blown into cracks and crevices, and could be inhaled by future tenants. "Tuberculous dust has been found by experiment to remain virulent and infectious for months and even years after it was deposited." ${ }^{123} \mathrm{Had}$ the expectorate or dust been exposed to either direct or diffused sunlight, the bacillus would have died in a matter of minutes to days. Had the tenement apartment been properly ventilated, the dust would not have been allowed to settle, and might perhaps have been carried outdoors. "But in too many houses in New York City there is never sufficient thorough cleaning to remove the infection, and sunlight, daylight, and fresh air sufficient to destroy the tubercle bacilli cannot enter."'124

Like their working and housing conditions, the living habits of immigrant Jews affected their health. Wages were low and rents high, so families took in boarders who paid 10c. a night to sleep; meals cost extra. At one time or another, most people either had or were boarders. Boarders constituted 7 per cent of the population in the Baron de Hirsch census. ${ }^{125}$ The emotional stress of this situation and the strains it put on family life will be discussed later. The important point here is that boarding increased congestion, lowered the standard of living, and increased the risk of contagious infection.

An exhibit concerning the evils of housing congestion was held in 1908 at New York's American Museum of Natural History. One display of a census of 250 "typical" Lower East Side families showed that 50 per cent slept three or four per room, 25 per cent slept two per room, and the rest slept five or more per room. ${ }^{126}$ This was, if anything, an improvement on former sleeping arrangements. George Price recalled that during his tenure working for the Sanitary Society in the 1880s, "in one home, consisting of three rooms (each eight by ten or nine feet), you could find a family made up of the husband, the wife, a sick father, and six children, ranging from

\footnotetext{
120 Annual report of the University Settlement Society, 1897, p. 29.

121 Jacob Riis, Children of the poor, London, Sampson, Low, Marston, 1892, p. 37.

122 Veiller and De Forest, op. cit., note 31 above, vol. I, p. 448.

123 Ibid., p. 464.

124 Ibid., p. 447.

125 Gartner, op. cit., note 56 above, p. 270.

${ }^{126}$ Miller, op. cit., note 53 above, p. 10270.
} 


\section{Deborah Dwork}

one month to thirteen years, and thirteen roomers who came to sleep in these rooms"'127 - a total of twenty-two people. According to Dr. Biggs of the Health Department, "The density of population always bears a more or less constant ratio to the prevalence of tuberculosis, the mortality increasing with an increasing density." 128

We have already discussed the common misconception that past poverty was "clean". The equally common idealization that immigrant Jewish housewives were particularly fastidious housekeepers is contradicted by the immigrant literature and the reports and memoirs of settlement workers. Immigrants from the ghettos of Eastern European cities had no training in hygiene or housekeeping. And the habits of immigrants from the villages and shtetls - sweeping dirt floors and airing the bedding - were not adaptable to the congested, airless quarters of New York. None of the immigrants was prepared for the degree of urbanization found in New York, and cleanliness in the home suffered accordingly. In a discussion about hygiene education for Jewish immigrants, Jacob Riis wrote, "The homes are too hopeless, the grind too unceasing. The [teachers] know it, and have little hope of the older immigrants." 129 Even those immigrants who either came with or learned clean habits found that maintaining sanitary conditions was next to impossible. There was rarely hot water in the apartment, and often no running water at all. There were few bathrooms and wash basins. Closet space was minimal. To thwart further efforts at sanitation, garbage collection and street cleaning were erratic before 1894. As if the lack of space and paucity of facilities were not bad enough, immigrant women were stymied by their ignorance of ways to deal with them. Jewish immigrant females were far less educated than their male counterparts, and the untrained, untutored mind often cannot devise ingenious methods to cope with a new environment.

Social habits were frequently not conducive to good health. There was "not even enough crockery or eating things. Two soup plates must do for the four of us. Mother has it that respectability requires that the family must eat together. So mother and father eat out of one plate and Philip and I share the other." 130 Often, people simply ate with their fingers. ${ }^{131}$ Expectorating was a common habit. "Everybody is busy spitting," one immigrant wrote. ${ }^{132}$

Finally, some habits which evolved in an effort to cope with living conditions were potentially harmful. To escape the hot, airless rooms in summer, people slept on the roofs and fire-escapes, frequently without precautions against falling. Because there was no refrigeration and few people had ice boxes, food was kept on the fire-escape or window-sill on the airshaft, exposed to insects and vermin.

Food shopping was primarily done within the Jewish district. The central shopping area was the Hester Street Market (Fig. 6), where housewives believed great bargains could be obtained from pushcart peddlars. Small quantities were bought at a time; a few cents' worth of milk was purchased in the shopper's own vessel, and butter was

\footnotetext{
127 Price, op. cit., note 22 above, p. 54.

128 Veiller and De Forest, op. cit., note 31 above, vol. I, p. 447.

${ }^{129}$ Riis, op. cit., note 121 above, pp. 56-57.

${ }^{130}$ Ornitz, op. cit., note 99 above, p. 29.

131 Yezierska, op. cit., note 14 above, p. 101.

132 Ornitz, op. cit., note 99 above, p. 138.
} 
sold in pats. The most commonly purchased items were flour, sugar, coffee (one pound sufficed a family of six for three weeks), eggs, beans, rice, rye bread, rolls for breakfast, milk, butter, and dried fruit. ${ }^{133}$ Fish, either fresh or tinned, was a staple in the diet of the immigrant Jew. Fresh kosher meat and poultry were less common and sold in small quantities. A common diet included rolls and coffee or tea for breakfast; a hunk of bread and a few cents' worth of herring for lunch; and, for dinner, soup, bread, potatoes, and a bit of baked fish or roasted or boiled (in the soup) meat or poultry. ${ }^{134}$ Herring was probably the single most common food eaten by immigrant Jews, and in 1898 cost between two and four cents a pound. ${ }^{135}$

Very poor Jewish families "live[d] for days on bread, herring and tea alone."136 People were forced by poverty to go to great lengths to obtain cheaper food. They bought stale bread, bruised or near rotten produce (pickles, onions, potatoes, and cabbage were the most popular vegetables), and the dregs of the fish stall or butcher's shop.

\section{VII}

The tenth ward of New York was the dirtiest and most crowded district in the city. Jews lived there amid incredible congestion and squalid working, housing, and living conditions. Yet, surprisingly, a review of the incidence of the disease* among Jews in the Lower East Side shows that the tenth ward was the healthiest in New York. ${ }^{137}$ In 1890, 22,000 Jews reported themselves as being in good health, while 657 rated their health as not good. ${ }^{138}$ The Charity Organization Society (COS) in 1902 appointed a Committee on the Prevention of Tuberculosis, consisting of sixteen physicians and sixteen interested lay persons to study the social aspects of the disease and to educate the medical, political, and general community about the proper prevention of and care for tuberculosis. The Committee's report revealed many interesting facts about Jewish disease rates. The death rate from consumption per 100,000 people between fifteen and forty-four years of age in 1900 was listed according to birthplace of mothers. The death rates for Russians, Hungarians, and Poles, "nearly all Jews", were 131.1, 113.5 and 67.4 respectively. ${ }^{139}$ These were the lowest mortality rates from consumption for all nationalities. When these figures were further scrutinized, they indicated a difference between male and female susceptibility to the disease. In 1902, 29 per cent of all deaths among Russian and Polish men in Manhattan and the Bronx were due to consumption. The percentage of deaths among females was much lower: 16.6 per cent. The figure for males was the third lowest and for females the lowest among all

\footnotetext{
133 Annual report of the University Settlement Society, 1898, pp. 15-19.

${ }^{134}$ Oral history, Mrs. R., now living in New Haven, Conn.

135 Annual report of the University Settlement Society, 1898, p. 19.

${ }^{136}$ Maurice Fishberg, 'Health and sanitation of the immigrant Jewish population of New York', Menorah Monthly, August 1902, 33: 77.

*Due to statistical limitations, I deal largely with mortality and not morbidity rates.

137 Riis, op. cit., note 121 above, p. 40.

133 Gartner, op. cit., note 56 above, p. 271.

${ }^{139} \mathrm{COS}$, Handbook on the prevention of tuberculosis, New York, 1903, pp. 53, 55.
} 


\section{Deborah Dwork}

nationalities in New York. ${ }^{140}$ This was among the largest differences in disease susceptibility found between the sexes. It was believed to be "due to the Jewish ideals which keep the woman in the home, and protect her as far as possible from the struggle for existence, as well as to the almost incredible efforts which the husband and father makes in the struggle, and the character of his usual occupations." 141

Similarly, death rates according to occupation proved lower in Jewish industries than would have been expected considering the working conditions. Tailoring combined many of the characteristics of employment which were thought to make consumption especially prevalent: low wages which caused privation at home, unsanitary conditions in the shop, exposure to "fly" from cloth, continued strained work position, close confinement within doors, and long and irregular hours. Yet the death rate from consumption among tailors was 218.2 per 100,000 , well below the average of $240 .{ }^{142}$

Consumption statistics were also studied in relation to density of population (Table VI) and quality of housing. Despite dense population, the Jewish quarter as a whole had the lowest mortality rates from consumption in the city. "It is the large Hebrew element in the tenth ward ... which gives this notoriously congested spot a comparatively low rate of tuberculosis. For the same reason the seventh, eleventh and thirteenth, which rank next the tenth in density, have the very least consumption." ${ }^{143}$

TABLE VI. RELATIONSHIP BETWEEN DENSITY AND TB DEATH RATE IN THE JEWISH WARDS OF NEW YORK, 1890 AND $1900^{\mathrm{a}}$

\begin{tabular}{l|r|r|r|r|r|r|r|r}
\hline & \multicolumn{2}{|c|}{ Ward 7 } & \multicolumn{2}{c|}{ Ward 10 } & \multicolumn{2}{c|}{ Ward 11 } & \multicolumn{2}{c}{ Ward 13 } \\
\cline { 2 - 9 } & 1890 & 1900 & 1890 & 1900 & 1890 & 1900 & 1890 & 1900 \\
\hline Population & 57,366 & 89,237 & 57,596 & 71,879 & 75,426 & 99,144 & 45,884 & 64,117 \\
\hline Persons per acre & 290 & 478 & 524 & 653 & 385 & 513 & 429 & 599 \\
\hline Rank according to density* & 6 & 4 & 1 & 1 & 3 & 3 & 2 & 2 \\
\hline Death rate/100,000 from TB $\dagger$ & 373 & 156 & 307 & 201 & 328 & 136 & 284 & 102 \\
\hline Rank according to death rate** & 7 & 3 & 4 & 5 & 6 & 2 & 2 & 1. \\
\hline
\end{tabular}

${ }^{a}$ Charity Organization Society, $A$ handbook on the prevention of tuberculosis, (Lilian Brandt), 1903 , p. 85.

"Rank figures indicate relationship to the other wards, "l" being the most densely populated.

**Rank figures indicate relationship to the other wards, " 1 " having the lowest death rate.

†Death rate and rank are for the years 1890 and 1901.

The death rate, however, may not have been an accurate index to morbidity from tuberculosis. By 1906, 1,200 out of every 100,000 Jews living on the Lower East Side

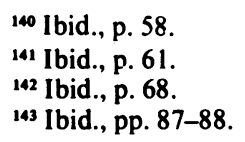


suffered from consumption. ${ }^{144}$ Statistics were also distorted because Jews were thought to have pthisis for an average of eight to ten years, compared with other peoples who died quickly from "fulminant" or "galloping" tuberculosis. By the time death occurred for a Jewish patient, it could have been recorded as due to another cause. ${ }^{145}$ By 1900, one-quarter to one-third of all deaths in New York among persons between the ages of fifteen and sixty-five were due to this most dreaded of diseases. ${ }^{146}$

Tuberculosis was not the only disease studied. According to the 1890 U.S. census report for New York City and Brooklyn, the mortality rates of those whose mothers were born in Russia and Poland were the lowest of all recorded nationalities $(1,485$ per 100,000$)$. Child mortality was also lowest among Eastern European Jews $(2,867$ per 100,000$)$. More specifically, death rates due to scarlet fever, consumption, measles, and diseases of the nervous system were lower in Jewish wards than in the city as a whole. The Jews were not so fortunate with regard to diphtheria and croup, diarrhoeal diseases, and pneumonia (Table VII).

TABLE VII. AVERAGE ANNUAL DEATH RATE PER 100,000 FROM VARIOUS DISEASES IN THE JEWISH WARDS AND NEW YORK CITY, $1890^{\circ}$

$\begin{array}{lccccccc} & \begin{array}{c}\text { Scarlet } \\ \text { fever }\end{array} & \begin{array}{c}\text { Diphtheria } \\ \text { and croup }\end{array} & \begin{array}{c}\text { Diarrhoeal } \\ \text { diseases }\end{array} & \begin{array}{c}\text { Consump- } \\ \text { tion }\end{array} & \text { Pneumonia } & \text { Measles } & \begin{array}{c}\text { Diseases of } \\ \text { the nervous } \\ \text { system }\end{array} \\ \text { New York City } & 52.19 & 181.63 & 316.85 & 391.75 & 287.89 & 45.67 & 241.96 \\ \text { Wards 7, 10,11, 13 } & 51.38 & 184.78 & 318.24 & 322.91 & 304.90 & 39.79 & 217.68 \\ \text { Ward 7 } & 52.96 & 174.62 & 326.55 & 373.15 & 365.89 & 36.63 & 239.39 \\ \text { Ward 10 } & 59.77 & 187.57 & 305.57 & 306.80 & 276.76 & 38.00 & 191.86 \\ \text { Ward 11 } & 48.16 & 181.73 & 315.54 & 327.58 & 281.69 & 44.53 & 219.67 \\ \text { Ward 13 } & 44.66 & 195.19 & 325.32 & 284.12 & 295.29 & 40.04 & 219.83\end{array}$

a J. S. Billings, Vital statistics of New York and Brooklyn, 1890, p. 250.

"In spite of narrow chests and slight stature, in spite of extreme poverty and still greater frugality, in spite of mental overexertion, lack of exercise, employment in the sweated industries, and the probability of contact with infection in second-hand clothing", ${ }^{147}$ and from living in such congested quarters without air or sunlight, Jews were not only healthier than their gentile immigrant neighbours, they were healthier than the Yankees. This situation was not unique to New York. According to John Shaw Billings's special census report, the average annual mortality among Jews living in the U.S. was 711 per 100,000 population, or a little more than half that found among other people of the same social class. The statistics for deaths due to consumption in the country in general mirror the pattern found in New York City: the rate per 1,000 deaths was, among Jews (1890), 36.67 for males and 34.02 for females, while in the total population (1880) it was 108.79 and 146.12 respectively. ${ }^{148}$ As noted above,

144 Howe, op. cit., note 9 above, p. 149.

145 COS, op. cit., note 139 above, p. 56.

146 Veiller and De Forest, op. cit., note 31 above, vol. I, p. 448.

${ }^{147} \mathrm{COS}$, op. cit., note 139 above, p. 56.

148 John Shaw Billings, Vital statistics of the Jews in the United States, Special report for the Eleventh Census of the United States (Census Bulletin No. 19), Washington, D.C., G.P.O., 1894, p. 10. 


\section{Deborah Dwork}

the mortality rate of children under fifteen years old was lowest (of a total of nine nationalities) among those whose mothers were born in Russia and Poland (2,867 per $100,000)$. The mortality rate of those whose mothers were born in the United States was 5,401 per 100,000 .

This general pattern of a lower mortality rate among Jews, and specifically lower mortality rates from consumption and among children, is found in Europe as well. In Budapest during the years 1885-1893 the general death rate for Jews was approximately half that of Christians. ${ }^{149}$ Similarly, in Prussia during the years 1888-1892, the mortality rate among Jews was 1,571 per 100,000 population as compared with 2,326 among Christians, and from 1893 to $1897,1,473$ as compared with 2,184. ${ }^{150}$ There are numerous and extensive studies on comparative mortality rates from tuberculosis which indicate a consistently lower rate among Jews. The mortality rate from consumption per 100,000 population in Tunis (1894-1900) was 75 among Jews and 513 among non-Jews; in Berlin (1905) 98 per 100,000 among Jews and 216 among non-Jews; in Vienna (1901-1903), 179 and 496; in London (1901-1906) 133 and 179; in Cracow (1896-1900) 205 and 664; and in Budapest 219 and 460 respectively. ${ }^{151}$

The lower mortality among Jewish children was also noted with interest by several investigators, as infant mortality rates are a crucial index of the general state of health of a population. At a meeting of the British Medical Association in 1892, J. M. Rhodes presented figures showing that whereas there were 198 deaths per 1,000 children under one year old in the City of Manchester (1892), there were only 124 deaths per 1,000 in Cheetham, a densely populated and impoverished quarter of the city inhabited by Jews. This pattern continued; during the ten years 1894-1903 the average infant mortality in Cheetham was 115 as compared with 184 for the whole city. ${ }^{152}$ In Baden in 1882 the mortality rate of children under one year old was 220 per 1,000 live births among Jews, 280 among Protestants and 310 among Catholics. ${ }^{153}$ The Russian census of 1897 reported the low mortality of Jewish infants (up to one year) in the (agrarian) Pale of Settlement, with a rate of 132.1 deaths per 1,000 births as compared with 259.2 deaths among non-Jewish infants. ${ }^{154}$ Similarly, in Budapest between 1886 and 1890 the mortality rate of children under five years old was 76 per 1,000 among Jews and 160 among Catholics. ${ }^{155}$ The mortality statistics of Jewish children under fifteen years old in Prussia are remarkable. They were the lowest in Western Europe at the time. Between 1888 and 1892, 5.06 Jewish children less than fifteen years old died per 1,000 population, as compared with 12.17 Christian children, and

\footnotetext{
149 Josef von Körösi, Die Sterblichkeit der Haupt- und Residenzstadt Budapest von 1882-95 und deren Ursachen, Berlin, 1898.

${ }^{190}$ Arthur Ruppin, "Die Sozialen Verhăltnisse der Juden in Preussen”, Jahrb. Nationalökonomie und Statistik, 1902, p. 380.

151 Max Grunwald (editor), Die Hygiene der Juden, Dresden, Verlag der Historischen Abteilung der Internationalen Hygiene-Austellung, 1911, p. 294.

152 Ministry of Health (Gt. Britain), 42nd annual report on infant and child mortality, London, H.M.S.O., 1913, pp. 76, 79.

${ }^{153}$ Maurice Fishberg, 'Mortality', Jewiśh Encyclopedia, p. 31.

154 Voskhod, March, 1904, pp. 116-117, quoted in ibid., p. 33.

1ss Körösi, op. cit., note 149 above.
} 
between 1893 and 1897 the figures were 3.96 and 11.47 respectively. ${ }^{156}$ Of every 100 Jewish deaths in Prussia in 1907, 16.73 were children under fifteen years old, whereas among Christians there were 45.14.157

\section{VIII}

The reasons for this phenomenon were, and remain, unknown, but there was much speculation. At first, Jews were thought to be relatively immune to contagious disease, especially tuberculosis. ${ }^{158}$ When it became evident that this was not true, Jews were popularly endowed with a peculiar sort of resistance, "the special heritage of their race, a physical and nervous endurance." 159 This was most often ascribed to "agelong observance of the strict dietary regulations of Moses." 160

Contemporary medical and social investigators believed three major factors responsible for the Jews' generally low disease rates: rare alcoholism, religious law, and social customs. Alcoholism was known to increase susceptibility to tuberculosis, and Jews were correctly reputed to be not only infrequent alcoholics ("a rare vice among Jews"), ${ }^{161}$ but infrequent drinkers of alcohol at all. ${ }^{162}$

Jewish law was thought to be helpful in preventing contagion. Men were required to cut their finger- and toenails at least once a week, wash their hands before and after each meal, rinse out the mouth after each meal, and not walk four steps from bed without washing the face and hands. Jewish women were required to bathe at least once a month, and finger- and toenails were to be cut off frequently. Diet, too, was strictly regulated. There were rules for the slaughter of animals, and meat was thoroughly inspected by religious authorities before it was allowed to go on sale. The inspector examined the viscera, particularly expanding the lungs by blowing air into them. Sometimes this was done under water so that any perforation would be indicated by air bubbles rising to the surface. Any abnormality in any organ (e.g. adhesions, perforations, nodules) caused the entire animal to be discarded as unfit for human consumption. This rule was rather stringently enforced both in Russia and the United States: in Russia, 50 per cent of the slaughtered animals were rejected, and in the United States, 30 per cent. ${ }^{163}$ Moreover, meat and fowl were considered "kosher" or clean for only three days after slaughter. Thus, ingestion of infected meat was kept to a minimum.

By 1908, many of the theories relating observance of Mosaic law to low disease rates had been put into perspective by one of their formerly most ardent supporters. In an address before the Sixth International Congress on Tuberculosis, Dr. Maurice Fishberg, author of a comprehensive text on tuberculosis, gave a relatively new explanation for Jewish resistance to tuberculosis and to contagious disease in general.

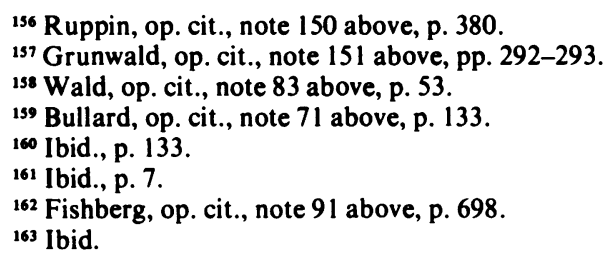




\section{Deborah Dwork}

The incidence of tuberculosis among Jews depends more on their economic and social environment than on racial or ritual affinities. ... The Jews have only the advantage of having passed through a process of infection during past centuries. Hence, their lower mortality today from tuberculosis ... the Jew does not make any material change in his milieu by changing his abode from eastern Europe to America. He lived there in a city, and here again settles in a city; he worked there at some indoor occupation, and does the same here; he lived there in an overcrowded dwelling, and moves here into a "double-decker" tenement. He has paid the price for urbanization already for several hundred years. ${ }^{164}$

Social customs of Jews were considered to be conducive to health. Although bathing was prescribed at set intervals by religious law, it was also simply customary. When Eastern European Jews came to New York, they built and operated sweat baths for profit. "The Russian baths are very numerous in the Jewish quarter, and very much frequented. "I cannot get along without a "sweat" (Russian bath) at least once a week,' many a Jew will tell you." 165 In 1880, possibly two of the twenty-four bathhouses in New York were owned by Jews; by 1897, over half of the city's sixtytwo bathhouses were Jewish-owned. ${ }^{166}$ Philanthropic and municipal organizations also accommodated the Jewish demand for baths by building bathhouses throughout the Lower East Side. At one bath opened in 1900 by the University Settlement, Jews willingly paid the 5c. charge for soap and towel, though the same nickel could have paid for a meal. ${ }^{167 *}$

Despite the grim conditions, Jewish housewives often succeeded in maintaining cleanliness in the home - a nearly impossible task. According to Lilian Brandt of the COS, Jewish homes were more hygienic than those of their Italian counterparts. ${ }^{168} \mathrm{Dr}$. Fishberg concurred, pointing out that contrary to the immediate impression of disorder in the kitchen upon entering a tenement home, close inspection revealed that the cooking range was kept sparkling clean. However, even Dr. Fishberg admitted that a rear bedroom was kept only as well as "the readiness of the housekeeper to work and clear it of vermin." 169 The home was cleaned at least once a week in preparation for the Sabbath, and was treated to a real "spring cleaning" prior to Passover. ${ }^{170}$

The kitchen was the focal point of the family, and preparation and consumption of food were of major importance. Contemporaries reported that "the Jew is well nourished ... as a whole his food is well chosen and better prepared ... than is that of the mass of industrial workers."171 If food was always a pre-occupation, it was imperative for the Sabbath and Passover. No matter how harried the week, how poor business, or how infrequently the entire family was assembled in one place, every Friday evening, the household sat down together for a full meal. Jacob Riis described such a scene:

164 Maurice Fishberg, 'Tuberculosis among the Jews', Sixth International Congress on Tuberculosis, vol. III: Hygiene, social, industrial and economic aspects of tuberculosis, Philadelphia, William F. Fell, 1908, pp. 423-425.

${ }^{165}$ Fishberg, op. cit., note 136 above, p. 74.

${ }^{166}$ Rischin, op. cit., note 4 above, p. 87.

167 Veiller and De Forest, op. cit., note 31 above, vol. II, pp. 35, 46-53.

*The University Settlement (on the corner of Rivington and Eldridge Streets) provided ten showers and three tubs. During the month of August, 4,919 baths were taken.

${ }_{160}$ COS, op. cit., note 139 above, p. 61

169 Fishberg, op. cit., note 136 above, p. 74.

170 Wheatley, op. cit., note 21 above, p. 327.

171 Pope, op. cit., note 63 above, pp. 176, 178. 
It happened once that I came in on a Friday evening at the breaking of bread, just as the four candles upon the table had been lit with the Sabbath blessing upon the home and all it sheltered. Their light fell on little else than empty plates and anxious faces; but in the patriarchal host who arose and bade the guest welcome with a dignity a king might have envied I recognized with difficulty the humble peddlar I had known only from the street. ... ${ }^{172}$

By and large, the Sabbath meal consisted of three courses: soup, the main dish (most popularly fish), potatoes, vegetables, braided bread, fruit and nuts, or cake (Fig. 7).

There was one class of illness which was more prevalent among Jews than other people, and for which urbanization in Eastern Europe was as inefficacious a preparation as cleaning, good housekeeping, and full meals were preventive. Jews suffered from mental and emotional disorders. As we have noted, these were sometimes due to the stress of work, with its busy and slack seasons. But the pain and rupture of dislocation caused other health problems with both physical and psychological manifestations. Neurasthenia and hysteria were more common among Jews than among other immigrants. Mental alienation was two to five times more frequent among Jews than non-Jews. Suicide, which was rare in Europe, was an ever more frequent occurrence in New York, ${ }^{173}$ and immigrants remember the headline "Genumen di gez" (took gas) appearing often in the Jewish newspapers.

The social manifestations of dislocation included a rise in venereal disease among Jews, although the numbers were still low compared to other groups. ${ }^{174}$ Prostitution, which is closely connected to venereal disease, was rampant on the Lower East Side for several reasons. The East Side housed many single men, men who had come alone either to earn money and return to their homelands, or, as with the Jews, to send for their families. Second, among religious Jews the woman is not a suitable sexual partner for approximately one third of every month. Third, the crowded living conditions may have inhibited sexual activity between husband and wife, thus creating a market for prostitution. And finally, there were few outlets for entertainment. Physical development and athletic activity were much deprecated by Jews, and many other sources of amusement were beyond their means.

Contemporary novels and reports on the "social evil" claimed that economic conditions and the lure of an apparently easy and luxurious life encouraged women to become prostitutes. Such was the finding of the Committee of Fifteen, a group of concerned New Yorkers who organized in 1900 to investigate and combat prostitution. Their report, published in 1902, stressed the economics of vice. "A season of nonemployment presents [industrial women] with the alternatives of starvation or prostitution." Alternatively, "they may be employed at living wages, but the prospect of continuing from year to year with no change from tedious and irksome labor creates discontent and eventually rebellion." 175

Important as was prostitution, the breakdown of the family was the most dramatic evidence of the stress of immigration. Husbands deserted wives, and children

172 Riis, op. cit., note 121 above, p. 44.

${ }^{173}$ Fishberg, op. cit., note 136 above, pp. 169, 172.

174 Ibid.. p. 174.

${ }^{17 s}$ The Committee of Fifteen, The social evil, New York, C.P. Putnam's Sons, 1902, p. 11. 


\section{Deborah Dwork}

abandoned their parents. Boarders and crowded conditions eroded family structure. "Seduction was commonplace, and many a man considered a trip across the ocean tantamount to a divorce." 176 Wife desertion became so common that the popular newspaper the Jewish Daily Forward, with the help of the National Desertion Bureau, ran a regular feature entitled "The Gallery of Missing Husbands". This published a picture and a short biography of the man, and requested him, or anyone who knew or saw him, to make his whereabouts known. The Jewish Information Agency also had a bureau seeking such husbands. In a column called the "bintel brief", which was Abraham Cahan's version of the modern "Dear Abby", the Forward printed letters asking for the return of errant husbands:

Max, where is your conscience: you used to have sympathy for the forsaken women and used to say their terrible plight was due to the man who left them in dire need. And how did you act?... Be advised that in several days I am leaving with my two orphans for Russia. We say farewell to you and beg you to take pity on us and send us enough to live on. ${ }^{177}$

Women on both sides of the ocean would frequently not admit that they were an "agunah", or deserted wife. The common explanation that the absent husband was away seeking work was used both legitimately and illegitimately. ${ }^{178}$ Women in Russia sometimes had to raise the money for passage themselves and then, alone or with children, emigrate to the United States in search of their husbands.

The system of boarding also created strains between husband and wife. Although some boarders fitted in like members of the family, relations were not always so cordial, and occasionally they were too cordial. Reformers blamed overcrowding and the system of lodgers for the immorality they found among the tenement population. Abraham Cahan's protagonist, David Levinsky, had amorous adventures with his landladies, and tried to convince one to leave her husband for him. David was not a "home wrecker"; he could not have disturbed a happy marriage. But his presence in the house exacerbated the problem of an unfulfilled husband-wife relationship.

Schism between parents and children was also a frequent outgrowth of the Americanization process. The children were educated in public schools; they spoke English and learned American habits. They were upwardly mobile. Through the parents' efforts, the children were educated beyond the parents' level and were able to achieve a higher social position. In a sense, then, the parents created monsters: they worked to have their children rise in society, learned to admire their children's achievements, and finally lost control of them. The exaggerated admiration for all that was "American" and upwardly mobile, and the concomitant scorn for all that was immigrant European, standards held by parent and child alike, created great familial stress. A popular saying at the time was, "In America, the children bring up the parents." ${ }^{179}$ One settlement worker observed the process of separation between parent and child:

At first the new ideas of the child are transmitted to its parents; but soon we find the [child] rapidly assimilating himself with our institutions and customs.... The home then becomes to the child a place to

\footnotetext{
${ }^{176}$ Ornitz, op. cit., note 99 above, p. 53.

1 Isaac Metzker, A bintel brief, Garden City, N.Y., Doubleday, 1971, p. 84.

17 Wald, op. cit., note 83 above, pp. 74-75

179 Metzker, op. cit., note 177 above, p. 24.
} 
sleep and eat.... It is no longer a home. ... The Jewish mother ... loves the child very much, so that after a time the child begins to control the parent instead of being controlled by her. ${ }^{100}$

Story after story by immigrant authors express the pain of this separation between parents and children - the bewilderment and anger of the older generation and the disgust and guilt of the younger. To Anzia Yezierska they were all "the children of loneliness".

\section{SUMMARY}

We have seen that despite the foul housing and work conditions, Jews on the whole were physically healthier than their neighbours, both immigrant and Yankee. The tenth ward was the healthiest in Manhattan; Jewish mortality rates for tuberculosis, measles, scarlet fever, and diseases of the nervous system were the lowest in the City. While Jews were physically healthy, however, they were not spared the emotional illnesses and conditions which stemmed from the rupture with tradition and the pain of dislocation. Depression, suicide, gonorrhoea, and nervous disorders were more common among European Jews in America than in the old country. Neurasthenia, hysteria, and mental alienation were more common among Jews than among their non-Jewish neighbours.

By and large the Jewish immigration was successful. Many people prospered and very few returned to Europe. They were, in addition, inordinately healthy. Yet scars were left as the immigrants passed through the crucible of Americanization.

\section{ACKNOWLEDGEMENTS}

I am very grateful to the men and women who spent many hours with me, remembering the days of their youth. From each I have the gift of a little bit of history. They gave not only their time, but also of themselves.

\section{BIBLIOGRAPHY}

\section{PRIMARY SOURCES}

\section{A. Official and annual reports of municipal, civic, and charity organizations}

1. Annual report of the Department of Street Cleaning, City of New York, 1914.

2. Annual reports of the University Settlement Society, 1894-1904, 1914, 1915-16. Also, University Settlement Studies Quarterly.

These reports are essential to any study of immigrant Jews on the Lower East Side of New York during those years.

3. Jewish Charity, New York, vols. 2, 3, 4, and 5(1903-1906).

4. The Committee of Fifteen, The social evil, New York, G. P. Putnam's Sons, 1902.

5. The Mayor's Committee on Public Baths and Public Comfort Stations, Report, New York, January 1897.

6. Society for the Alumni of City (Charity) Hospital, Report for 1904, New York City, 1904.

\section{B. Vital statistics and analyses}

1. Hermann M. Biggs, 'Preventive medicine in the City of New York', Br. med. J., 11 September 1897.

100 Annual report of the University Settlement Society, 1892, p. 27. 


\section{Deborah Dwork}

2. John Shaw Billings, Vital statistics of the Jews in the United States, and Vital statistics of New York City and Brooklyn, 31 May 1890, Special Reports for the Eleventh Census of the United States (1890), Washington, D.C., Government Printing Office, 1894.

3. Emil Bogen, 'Diseases among the Jews', Medical Leaves, 1943, 5: 151-159.

4. I. Davidsohn, 'Cancer among the Jews', ibid., 1939, 19-27.

5. Martin Engländer, Die Auffallend Häufige Krankheitserscheinungen der Jüdischen Rasse, Vienna, 1902.

6. Maurice Fishberg, 'The comparative pathology of the Jews', N.Y. med. J., 30 March 1901, pp. 537-543: 6 April 1901, pp. 576-581.

7. Maurice Fishberg, 'Health and sanitation of the immigrant Jewish population of New York', Menorah Mthly, August 1902, 33, no. 2: 73-82; September 1902, 33, no. 3: 168-180.

8. Maurice Fishberg, The Jews: a study of race and environment, London, Walter Scott, 1911.

9. Maurice Fishberg, 'Consumption', ‘Idiocy', ‘Insanity', ‘Morbidity', ‘Mortality’, in Jewish encyclopedia, 1901-1906 ed.

10. Max Grunwald (editor), Die Hygiene der Juden, Dresden, Verlag der Historischen Abteilung der Internationalen Hygiene-Ausstellung, 1911.

11. Hugo Hoppe, Krankheiten und Sterblichkeit bei Juden und Nichtjuden, Berlin, S. Calvary, 1903.

12. Joseph Jacobs, Statistics of the Jewish population in London, 1873-1893, London, E. W. Rabbinowicz, 1894.

13. Joseph Jacobs, Studies in Jewish statistics, London, D. Nutt, 1891.

14. Josef von Körösi, 'Einfluss der Confession des Wohlstandes und der Beschäftigung auf die Todesursachen', Publicationen des Statistischen Bureaus d. Hauptstadt Budapest, Berlin, 1898.

15. Joseph von Körösi, Die Sterblichkeit der Haupt- und Residenzstadt Budapest von 1882-95 und deren Ursachen, Berlin, 1898.

16. Lagneau, 'Discussion sur la pathologie de la race juive'. Bull. Acad. Méd. Paris, 8 September 1891.

17. Cesare Lombroso, L'antisemitismo e le scienze moderne, Turin, 1894.

18. Ministry of Health (Great Britain), 42nd annual report on infant and child mortality, London, H.M.S.O., 1913, pp. 19, 76, 79.

19. Alfred Nossig, Jüdische Statistik, Berlin, 1903, esp: H. Rimalovsky, 'Zur Statistik der Bulgarischen Juden', pp. 316-321; L. Wengierow, 'Die Juden in Königreich Polen', pp. 293-310.

20. Sir Humphry Rolleston, 'Some diseases in the Jewish race', Bull. Johns Hopk. Hosp., 1928, 43: 117-139.

21. Arthur Ruppin, The Jews of today, London, G. Bell, 1913.

22. Arthur Ruppin, 'Die Sozialen Verhältnisse der Juden in Preussen', Jahrb. Nationalökonomie und Statistik, 1902.

23. Heinrich Singer, Allgemeine und Spezielle Krankheitslehre der Juden, Leipzig, B. Konegen, 1904. 
24. Thirteenth Census of the United States (1910), vol. III, 'Population', Washington, D.C., Government Printing Office.

25. Hugo Ullmann, 'Zur Frage der Vitalität und Morbidität der Jüdischen Bevölkerung', Arch. Rassen- und Gesellschafts-Biologie, vol. 18, Munich, 1926, pp. 1-54.

26. Also, various reports in: Bulletin of the International Statistical Institute; Statisches Jahrbuch der Stadt (Berlin); Veröffentlichungen des Bureaus für Statistik der Juden.

C. Industry, industrial conditions, industrial health

1. Joint Board of Sanitary Control in the Cloak, Suit, and Skirt Industry, Directory of certificated shops in the cloak, suit, and skirt industry, New York, Allied Printers, May 1913.

2. Joint Board of Sanitary Control in the Cloak, Suit, and Skirt Industry, First annual report, New York, October 1911.

3. Joint Board of Sanitary Control in the Cloak, Suit, and Skirt Industry, Six years' work and progress of the Joint Board of Sanitary Control in the Cloak, Suit, and Skirt, and Dress and Waist Industries, New York, October 1916.

4. Joint Board of Sanitary Control in the Dress and Waist Industry, Special report on sanitary conditions in the shops of the dress and waist industry, New York, Allied Printers, May 1913.

5. Jesse Eliphalet Pope, The clothing industry in New York, University of Missouri, 1905.

6. Edward E. Pratt, Industrial causes of congestion of population in New York City, Columbia University Ph.D. thesis, New York, 1911.

7. Preliminary report of the Factory Investigating Commission of the State of New York, 1912, vols. I, II, and III, Albany N.Y., Argus, 1912.

8. George Price, Handbook on sanitation, New York, John Wiley, 1911.

9. George Price, Report for the year 1926 of the Union Health Center, New York, Allied Printers, 1926.

10. George Price and Theresa Wolfson, Seating and posture, New York, Allied Printers, 1923.

11. George Price, Ten years of industrial sanitary self control; the Tenth Annual Report of the Joint Board of Sanitary Control in the Cloak, Suit, and Skirt, and Dress and Waist Industries, New York, 1921.

12. George Price, The Joint Board of Sanitary Control in the Cloak, Suit, and Skirt, and Dress and Waist Industries, New York, October 1924.

13. George Price, The modern factory, New York, John Wiley, 1914.

14. George Price and Rudolph Miller, Fire hazard in factory buildings, New York, December 1922.

15. Report for 1924 of the Union Health Center of the I.L.G.W.U. New York Locals, New York, Allied Printers, 1924.

16. J. Schereschewsky, 'The health of garment workers', Publ. Hlth Bull., no. 71, May 1915. 


\section{Deborah Dwork}

17. J. Schereschewsky and D. H. Tuck, 'The hygienic conditions of illumination in workshops of the women's garment industry', ibid.

18. Second report of the New York State Factory Investigating Commission, January 1913, vols. I and II, Albany, N.Y., J. B. Lyon, 1913.

19. Transactions of the Fifteenth International Congress on Hygiene and Demography, Washington, D.C., Government Printing Office, 1913. Especially: vol. III, part I, 'Hygiene of infancy and childhood: school hygiene'; vol. III, part II, 'Hygiene of occupations'; vol. IV. part I, 'Control of infectious diseases'; vol. IV; part II, 'State and municipal hygiene'.

20. Twelfth annual report of the Factory Inspector of the State of New York (1897), New York, 1898.

21. B. S. Warren and Edgar Sydenstricker, 'Health of garment workers', Publ. Hlth Rep., 26 May 1916, 31, no. 21.

D. Tuberculosis

1. Emil Bogen, 'Tuberculosis among the Jews', Medical Leaves, 1940, 3: 123-129.

2. Charity Organization Society (COS), $A$ handbook on the prevention of tuberculosis; the first annual report of the Committee on the Prevention of Tuberculosis of the COS, New York, 1903; Second annual report, 1903-04; Third annual report, 1904-05.

3. COS, Preventing tuberculosis in New York City, Ninth annual report of the Committee, [n.d.].

4. Department of Health, City of New York, Clinic for the Treatment of Communicable Pulmonary Diseases, First report, 1906.

5. Department of Health of the City of New York and the Committee on the Prevention of Tuberculosis of the COS, What you should know about tuberculosis, New York City, 1910.

6. Maurice Fishberg, 'The relative infrequency of tuberculosis among the Jews', Amer. Med., 1901, 2: 695-698.

7. S. A. Knopf, Tuberculosis as a disease of the masses and how to combat it, New York, Fred P. Flori, 1907.

8. John H. Pryor, 'The tenement and tuberculosis', Charities Rev., 1900-1901, 10: $440-446$.

9. Sixth International Congress on Tuberculosis, Philadelphia, William F. Fell, 1908; especially vol. III: Hygienic, social, and industrial, and economic aspects of tuberculosis.

10. 'Studies in immunity to tuberculosis', J. med. Res., April 1910, 22, no. 2.

11. 'Tuberculosis among Jews', Br. med. J., 1908, i: 1000-1002.

12. Tostivint and Remlinger, 'Note sur la rareté de la tuberculose chez les Israélites Tunisiens', Rev. Hyg. Police Sanitaire, Paris, 1900, 22: 984-986.

\section{E. Tenements}

1. Lawrence Veiller and Robert De Forest (editors), The tenement house problem, 2 vols., New York, Macmillan, 1903.

2. Fifth Report of the Tenement House Department of the City of New York, 1909, 
Health conditions of immigrant Jews on the Lower East Side of New York: 1880-1914

New York, J. J. Little \& Ives.

3. Joseph Lee, 'Preventive work', Charities Rev., 1900-1901, 10: 469-485.

4. Sixth report of the Tenement House Department of the City of New York, New York City, Allied Printing, 1910-1911.

5. Plumber and Sanitary Engineer, March 1879, 2, no. 4: 89-91; December 1878, pp. 1, 32.

F. Social commentaries, tracts, pamphlets, and articles

1. Annie S. Daniel, 'The wreck of the home', Charities, 1905, 14: 624-629.

2. Harold M. Finley, 'The congestion of Manhattan', Federation, May 1908, 5, no. 3: 10-18; also, entire issue of Federation, April 1906, 4, no. 3.

3. Burton J. Hendrick, 'The Jewish invasion of America', McClure's Mag., March 1913, pp. 126-165.

4. Arthur Henry, 'Among the immigrants', Scribner's Mag., 1901, 29: 301-311.

5. Claude H. Miller, 'The menace of crowded cities', World's Work, 1908, 16: 10268-10272.

6. George Price, 'The Russian Jews in the United States', Amer. Jew. hist. Soc., September 1958, 48, no. 1: 28-62; ibid., December 1958, 48, no. 2: 78-133.

7. Jacob Riis, How the other half lives, New York, Hill \& Wang, 1957.

8. Jacob Riis, The children of the poor, London, Sampson, Low, Marston, 1892.

9. Jacob Riis, The peril and the preservation of the home, Philadelphia, George W. Jacobs, 1903.

10. Jacob Riis, $A$ ten years' war, Boston and New York, Houghton, Mifflin, 1900.

11. Mary Sherman, 'Manufacturing of foods in the tenements', Charities and the Commons, 1905-06, 15: 669-672.

12. 'The moral side of the tenement problem', Catholic Wld, May 1885, 41: 160-164.

13. Richard Wheatley, 'The Jews in New York', Century Mag., January 1892, 43, no. 3: 323-342.

G. Fiction, fictionalized accounts

1. Sholem Aleichem, 'Off for the Golden Land', Jewish Immigration Bull., February 1917, pp. 10-11.

2. Arthur Bullard, Comrade Yetta, New York, Macmillan, 1913.

3. Abraham Cahan, The imported bridegroom and other stories, Boston and New York, Houghton, Mifflin, 1898.

4. Abraham Cahan, The rise of David Levinsky, New York, Harper, 1917.

5. Michael Gold, Jews without money, New York, Horace Liverwright, 1930.

6. Hutchins Hapgood, The spirit of the ghetto, Cambridge, Mass., Belknap Press of Harvard University Press, 1967.

7. Theresa Server Malkiel, The diary of a shirtwaist striker, New York, Socialist Literature, Co-Operative Press, 1910.

8. I. L. Nascher, The wretches of Povertyville, Chicago, Joseph J. Lanzit, 1909.

9. James Oppenheim, Doctor Rast, New York, Sturgis \& Walton, 1909.

10. S. B. Ornitz, Haunch, paunch and jowl, New York, Boni \& Liverwright, 1923.

11. Ernest Poole, His family, New York, Macmillan, 1917.

12. Ernest Poole, His second wife, New York, Macmillan, 1918. 


\section{Deborah Dwork}

13. Ernest Poole, The harbor, New York, Macmillan, 1915.

14. Jacob Riis, Children of the tenements, New York, Macmillan, 1903.

15. Jacob Riis, Neighbors, New York, Macmillan, 1919.

16. Jacob Riis, Out of Mulberry Street, New York, Century, 1898; republished 1970 by Literature House.

17. Irvin Swerdlow, All for one, New York City, I.L.G.W.U. Education Department, [n.d.].

18. Anzia Yezierska, Children of Loneliness, New York and London, Funk \& Wagnalls, 1923.

19. Anzia Yezierska, Hungry hearts, Boston and New York, Houghton, Mifflin, 1920.

20. Anzia Yezierska, Salome of the tenements, New York, Boni \& Liverwright, 1923.

H. Memoirs, autobiography

1. Charles Bernheimer, Half a century in community service, New York, Association Press, 1948.

2. Miriam Blaustein, Memoirs of David Blaustein, New York, McBride, Nast, 1913.

3. Michael Charnofsky, Jewish life in the Ukraine, New York, Exposition Press, 1965.

4. Fannie Edelman, The mirror of life, New York, Exposition Press, 1961.

5. Emma Goldman, Living my life, Garden City, N.Y., Garden City Publishing Co., 1931.

6. Benjamin Lee Gordon, The memoirs of a physician, New York, Bookman Associates, 1962.

7. Mary Asia Iliff, No time for tears, New York, Thomas Yoseloff, 1964.

8. Oral histories, especially from the men and women of the Golden Age Club and the Happy Club of the Mosholu Montefiore Senior Center, DeKalb Avenue, Bronx, New York 10467.

9. Lillian Wald, The house on Henry Street, New York, Henry Holt, 1915.

10. Lillian Wald, Windows on Henry Street, Boston, Mass., Little, Brown, 1934.

11. Gregory Weinstein, The ardent eighties, New York, International Press, 1928.

12. Anzia Yezierska, Red ribbon on a white horse, New York, Charles Scribner's Sons, 1950.

\section{Miscellaneous}

1. Charles Bernheimer, The Russian Jews in the United States, Philadelphia, John C. Winston, 1905

2. Harry Chase Brearly, The problem of Greater New York and its solution, New York City, Search-Light Corporation, 1914.

\section{SECONDARY SOURCES}

\section{A. General}

1. Louis Finkelstein, The Jews, (vols. I and II), New York, Harper, 1960.

2. Irving Howe, World of our fathers, New York and London, Harcourt, Brace, Jovanovich, 1976. 
Health conditions of immigrant Jews on the Lower East Side of New York: 1880-1914

3. Moses Rischin, The promised city, Cambridge, Mass., Harvard University Press, 1962.

4. Ronald Sanders, The downtown Jews, New York, Harper \& Row, 1969.

5. YIVO Annual of Social Science, Yiddish Scientific Institute, New York. This is a necessary secondary source for any work in Jewish history. For the purposes of this work, volumes II/III, and IX are especially helpful.

\section{B. Population statistics}

1. Lloyd P. Gartner, 'The Jews of New York's East Side, 1890-1893', Amer. Jew. hist. Quart., March 1964, pp. 266-281.

2. Samuel Joseph, Jewish Immigration to the United States from 1881-1910, Ph.D. Thesis, Columbia University, New York, 1914.

3. Walter Laidlow, Population of the City of New York, 1890-1930, New York, Cities Census Committee, 1932.

4. Jacob Lestschinsky, 'Jewish migration, 1840-1956', in Louis Finkelstein (editor), The Jews, vol. II, New York, Harper, 1960.

C. Occupation distribution and labour unions

1. John Commons, History of labour in the United States, New York, Macmillan, 1918 (especially vol. II).

2. Max Danish, I.L.G.W.U. News-History 1900-1950.

3. Nathan Goldberg, 'Occupational patterns of American Jews', Jewish Rev., April 1945, 3, no. 1: 3-24.

4. Simon Kuznets, 'Economic structure and life of the Jews', in Louis Finkelstein (editor), The Jews, vol. II, New York, Harper, 1960.

5. Harry Lang, '62', Biography of a union, printed by Undergarment and Negligee Workers' Union, Local 62, of the International Ladies' Garment Workers Union, [n.d.].

6. Louis Levine, The women's garment workers, New York, B. W. Huebsch, 1924.

D. Public health and medical history

1. John Duffy, A history of public health in New York City, 1866-1966, New York, Russell Sage Foundation, 1974.

2. Mazÿck Ravenal, $A$ half century of public health, New York, American Public Health Association, 1921.

3. A. J. Rongy, 'Half a century of Jewish medical activities in New York City', Medical Leaves, Chicago, 1937, pp. 151-163.

4. George Rosen, Preventive medicine in the United States, New York, Science History, 1975.

\section{E. History of philanthropy}

1. Boris D. Bogen, Jewish philanthropy, New York, Macmillan, 1917.

2. Jewish Social Service Association, Fifty years of social service, New York City, 1926.

3. Roy Lubove, 'The New York Association for Improving the Condition of the Poor: the formative years', $N$. Y. hist. Quart., 1959, 43: 307-329. 


\section{Deborah Dwork}

F. Biography

1. R. L. Duffus, Lillian Wald, New York, Macmillan, 1939.

2. Roy Lubove, 'Annie Sturges Daniel', in Edward T. James (editor), Notable American women, 1607-1950, Boston, Mass., Harvard University Press, vol. I, 1971, pp. 429-431.

3. Med. J. Rec., 16 November 1927, p. 632, (obituary notice for William Gilman Thompson).

G. Newspaper articles (collections)

1. Isaac Metzker, $A$ bintel brief, Garden City, N.Y., Doubleday, 1971.

2. Allan Schoener, Portal to America, New York, Holt, Rhinehart \& Winston, 1967.

H. Miscellaneous

1. Ezekiel Lifschutz, 'Yiddish autobiographies as a source of American Jewish history', Amer. Jew. hist. Quart. March 1964, pp. 253-263.

2. Roy Lubove, The progressives and the slums, Pittsburgh, University of Pittsburgh Press, 1962. 